\title{
USO DE UM SISTEMA DE INFORMAÇÕES GEOGRÁFICAS NA ANÁLISE DE DISTRIBUIÇÃO DO VEADO-CAMPEIRO (Ozotoceros bezoarticus) NO PARQUE NACIONAL DAS EMAS, GOIÁS.
}

\author{
Natália Gonçalves Frutuoso \\ Bióloga
}

Orientador: Prof. Dr. CARLOS ALBERTO VETTORAzZI

\begin{abstract}
Dissertação apresentada à Escola Superior de Agricultura "Luiz de Queiroz", Universidade de São Paulo, para obtenção do título de mestre em Ciências Área de Concentração:Ciências Florestais.
\end{abstract}

P I R A C I C A B A

Estado de São Paulo - Brasil

$$
\text { Maio - } 1999
$$


FRUTUOSO, N.G. Uso de um sistema de informações geográficas na análise de distribuição do veadocampeiro (Ozotoceros bezoarticus) no Parque Nacional das Emas, Goiás.

\section{ERRATA}

$\begin{array}{lclll}p . & \text { item } & & \text { onde se le } & \text { leia-se } \\ 2 & 1 & \text { linha } 7 & \text {...ameaçado, pela distribuição... } & \text {...ameaçada pela destruição } \\ 2 & 1 & \text { linha } 10 & \text {...campos cerrados... } & \text {...campos limpos, sujos e cerrados } \\ 34 & 3.2 .3 .4 & \text { Tabela } 1 & \text { Mente } & \text { mente } \\ 43 & 4.2 .1 & \text { Figura } 6 & \text { Min } \mathrm{x}=318 & \text { Max } \mathrm{x}=318 \\ 44 & 4.2 .1 & \text { Figura } 7 & \text { Min } \mathrm{x}=318 & \text { Max } \mathrm{x}=318 \\ 49 & 4.2 .2 & \text { Tabela } 4 & \text { Campo } & \text { Hidro } \\ 57 & 4.2 .4 .2 & \text { Tabela } 5 & \text {...por pixel } & \text {...por valor de pixel } \\ 57 & 4.2 .4 .2 & \text { Tabela } 6 & \text { (substituir pela seguinte) } & \end{array}$

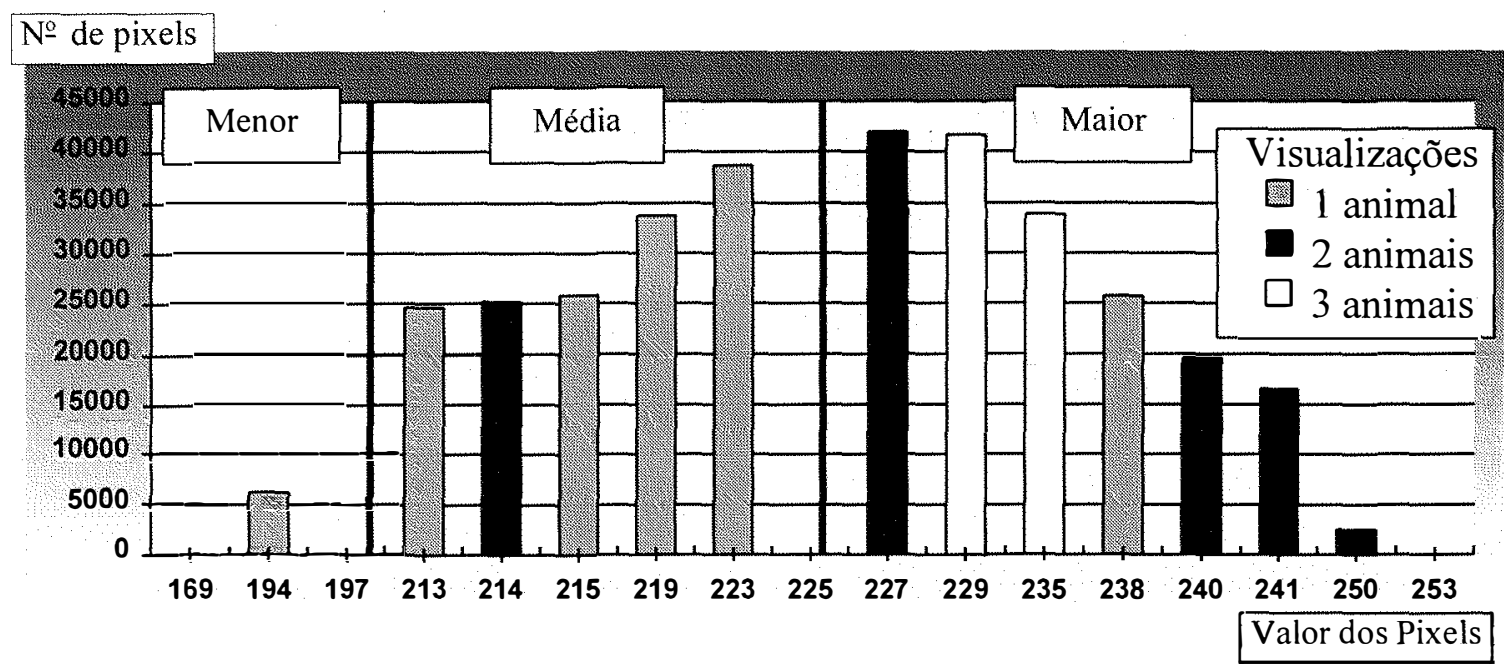

$\begin{array}{lllll}59 & 4.2 .4 .2 & \text { Tabela 7 } & \text { (Alta) } & \text { (Maior) } \\ 59 & 4.2 .4 .2 & \text { Tabela 7 } & \text { (Baixa) } & \text { (Menor) } \\ 60 & 4.2 .4 .2 & \text { linha 6 } & \text { (baixa... } & \text { (menor... }\end{array}$


Dados Internacionais de Catalogação na Publicação (CIP)

DIVISÃO DE BIBLIOTECA E DOCUMENTAÇÃO - Campus "Luiz de Queiroz"/USP

\section{Frutuoso, Natália Gonçalves}

Uso de um sistema de informaçōes geográficas na análise de distribuição do veadocampeiro (Ozotoceros bezoarticus) no Parque Nacional das Emas, Goiás / Natália Gonçalves Frutuoso. - - Piracicaba, 1999.

75 p. : il.

Dissertação (mestrado) - Escola Superior de Agricultura Luiz de Queiroz, 1999. Bibliografia.

1. Animal silvestre 2. Cerrado 3. Geoprocessamento 4. Parque Nacional das Emas 5. SIG 6. Veado campeiro I. Titulo

CDD 639.9797357

'Permitida a copia total ou parcial deste documento, desde que citada a fonte 0 Autor" 


\title{
USO DE UM SISTEMA DE INFORMAÇÕES \\ GEOGRÁFICAS NA ANÁLISE DE DISTRIBUIÇÃO DO \\ VEADO-CAMPEIRO (Ozotoceros bezoarticus) NO \\ PARQUE NACIONAL DAS EMAS, GOIÁS.
}

\author{
NATÁLIA GONÇALVES FRUTUOSO
}

Aprovado em:

Comissão Julgadora:

Prof. Dr. Carlos Alberto Vettorazzi

ESALQ/USP

Prof. Dr. Álvaro Fernando de Almeida ESALQ/USP

Prof. Dr. Luciano Martins Verdade

ESALQ/USP

Prof. Dr. CARLOS ALBERTO VETTORAZZI Orientador 
Aos Animais pela sua beleza e majestade.

À Natureza, em sua plenitude.

À grande Gaia, que acolhe seus filhos em seu ventre.

À grande Deusa, que ainda vive nas almas adormecidas de seus filhos.

À Lua, que possa ainda refletir sua face na água límpida.

À Água, que alimenta seus filhos em silêncio.

À Isís, que a Humanidade possa levantar seu véu para a luz do conhecimento.

Aos grandes mestres, que em sua piedade mantém Gaia viva, apesar da obscuridade humana.

Por favor nos perdoem, por nossas almas adormecidas.

E que se cumpra a grande lei da evolução.

\section{DEDICO}

A todos os seres vivos, pela grande vitória de superar, ao longo de milhares de anos de existência, todos os obstáculos que os impedem de continuar na Terra. Que continuem tendo este grande poder de vencer!

\section{OFEREÇO}




\section{AGRADECIMENTOS}

Ao professor e orientador Dr. Carlos Alberto Vettorazzi (ESALQ/USP) pela paciência e o grande auxílio dado na realização da dissertação.

Aos coordenadores do Projeto Cervídeos do Brasil, da UNESPJaboticabal, Prof. Dr. José Maurício Barbanti Duarte e Prof. Dr. Mateus José Rodrigues. Paranhos da Costa, pela atenção especial dada ao meu projeto, cedendo o veículo do Projeto, dados do mesmo Projeto e grande auxilio técnico para execução de minha dissertação.

À auxiliar técnica do Projeto Cervídeos, Celeste Marise da Silva, por seu amor à fauna e ao Parque, que muito me auxiliou na dissertação, pelo seu conhecimento do veado-campeiro e do Parque, pelo carinho de seus filhos Alexandre e Juliana, e hospitalidade de seu marido Geovane.

Especial agradecimento à Fundação $\mathrm{O}$ Boticário de Proteção à Natureza, pelo grande apoio financeiro dado ao projeto, favorecendo, em muito, a realização do mesmo.

Ao Ibama, pela autorização de permanência no Parque e apoio.

Ao Diretor do Parque Nacional das Emas, Ary Soares dos Santos, pela assistência dada ao projeto, e aos funcionários do Parque, Zé Carlos, que muito me ajudou na realização do projeto, Edmar, apesar dos percalços no meio do caminho, e aos demais funcionários do Parque.

À comunidade de Mineiros, pela simpatia e hospitalidade de sua cidade, principalmente à Maristela de Paula Carvalho e sua familia, pela grande amizade, carinho e auxilio para comigo, que muito me ajudaram e ainda continuam a me acolher nas horas dificeis.

Ao Sr. Kenith, que muito me auxiliou, para encontrar o avião para o projeto, e ao Zilmar pela força dada ao projeto e seu carinho pelo Parque.

À comunidade de Chapadão do Céu, pela hospitalidade, principalmente ao mecânico Ronaldinho pelas diversas assistências dadas ao fusca e a todos que de certa maneira acudiram o fusca nas horas dificeis. 
Ao fazendeiro Eduardo Peixoto, pelo vôo realizado em seu ultraleve no Parque, para o projeto, e a simpatia de sua esposa.

Ao aeroclube de Jataí, principalmente ao piloto Olavo, pela paciência e auxílio de grande valor ao projeto.

Ao Biólogo Mário Barroso (USP), pelo empréstimo dos mapas do parque, arquivos digitais, gravador portátil, comentários, assistência dada ao projeto e principalmente o grande amor e dedicação ao Parque.

A Bióloga Helena de Franca (INPE), pelo empréstimo das imagens orbitais do Parque e grande auxílio técnico sobre o mesmo.

Ao Prof. Dr. Hilton Thadeu Zarate do Couto (ESALQ/USP), pelo grande apoio estatístico e financeiro dado ao projeto.

Ao Prof. Dr. Jansle Vieira Rocha (UNICAMP), pela apresentação e aprendizagem inicial do SIG, no software Idrisi.

Ao Prof. Dr. Álvaro Fernando de Almeida (ESALQ/USP), por acreditar em mim.

Ao Prof. Dr. Leopoldo M. Coutinho (USP), pelos ensinamentos recebidos sobre o cerrado, no próprio Parque.

Ao CEMASI (Centro de Monitoramento e Proteção Ambiental do Itapety) pela administração financeira do projeto, por meio de Lucila Manzatti.

Ao técnico Jesuíno Ferrari (ESALQ/USP), pela colaboração na parte topográfica, e ao estagiário Silvio, do Departamento de Ciências Florestais (ESALQ/USP), pela valiosa colaboração na digitalização dos mapas e uso dos softwares Idrisi e Surfer.

Às bibliotecárias do Museu de Zoologia do Estado de São Paulo, que me auxiliaram inúmeras vezes, mesmo no tempo de graduação. Um especial agradecimento à Baby.

Aos companheiros dos Departamento de Ciências Florestais e Engenharia Rural (ESALQ/USP), principalmente a amizade e apoio dos engenheiros Lothar (que muito me auxiliou na estatística), Parise e Axel. 
Às minhas amigas de república, Denise, Natália e Viviane, pelo apoio, e um especial agradecimento à nossa vizinha Rose e sua família, pela acolhida, carinho e ajuda, nas horas de complicações na casa.

À minha família, pelo apoio financeiro ao longo dos anos.

À Natureza em sua grandeza, que muito me fortalece e me ensina.

$\mathrm{E}$ a todas as pessoas que, ao longo de minha vida, me ajudaram de certa forma a chegar até aqui e poder realizar minha lenda pessoal e combater o bom combate. 
Página

LISTA DE FIGURAS ................................................................... ix

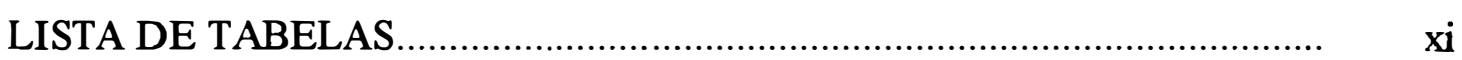

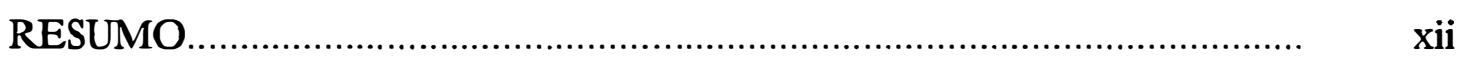

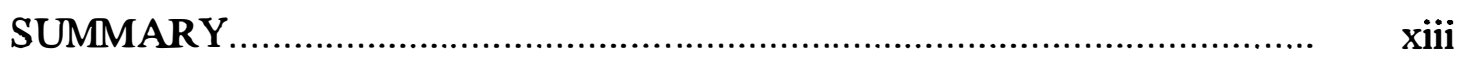

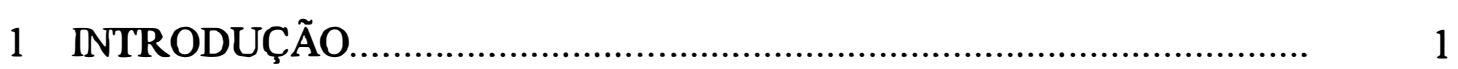

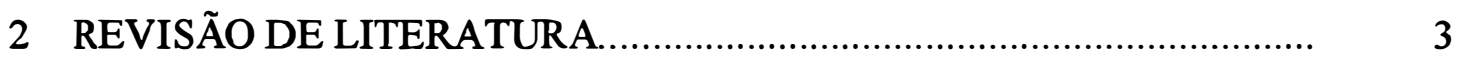

2.1 Análise da distribuição de animais.................................................. • 3

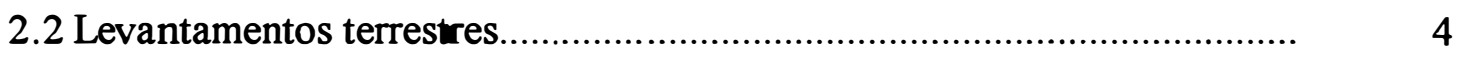

2.3 Levantamentos aéreos............................................................... 5

2.4 Levantamentos por sensoriamento remoto........................................ 7

2.5 Emprego de Sistema de Informações Geográficas (SIG)........................... 8

3 MATERIAL E MÉTODOS ............................................................ 13

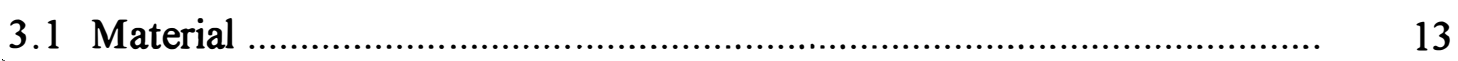

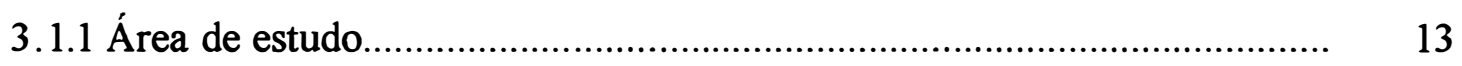

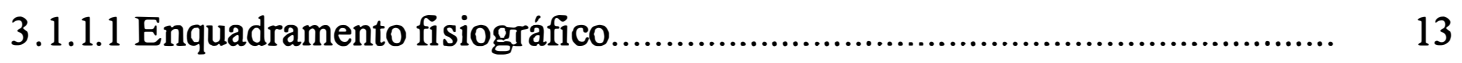

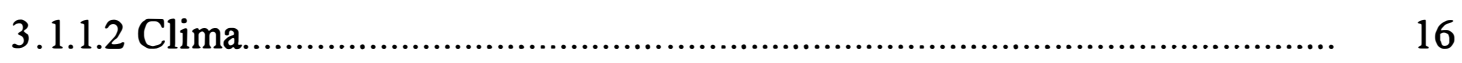

3.1.1.3 Hidrografia......................................................................... 16

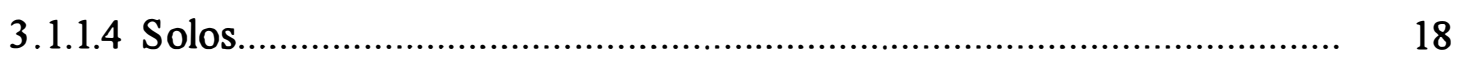

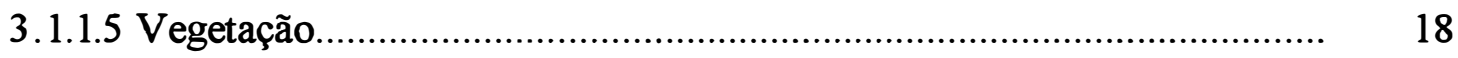

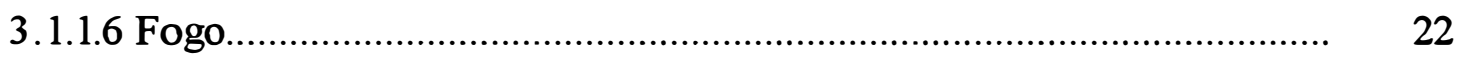

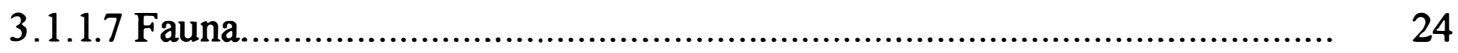

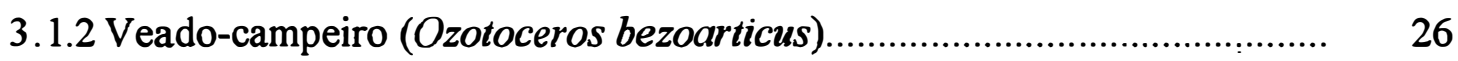

3.1.3 Mapas e equipamentos.............................................................. 30

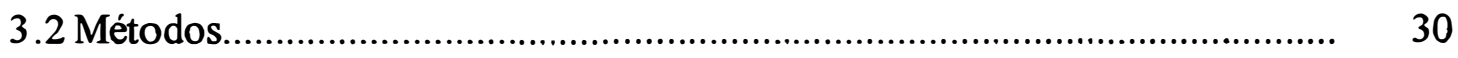

3.2.1 Levantamento bibliográfico e cartográfico das variáveis importantes ao

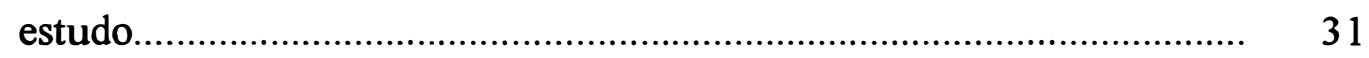

3.2.2 Trabalho de campo.................................................................... 31

3.2.3 Produção do mapa de probabilidade de ocorrência por meio de um SIG... 32 
3.2.3.1 Abordagem empregada................................................................... 32

3.2.3.2 Definição dos fatores e restrições........................................................ 33

3.2.3.3 Digitalização dos planos de informação...................................................... 33

3.2.3.4 Cálculo dos pesos dos planos........................................................ 34

3.2.3.5 Geração do mapa de maior probabilidade de ocorrência........................... 35

3.2.4 Amostragem por meio de levantamento aéreo.......................................... 35

3.2.5 Amostragem terrestre ............................................................................ 37

3.2.6 Análise estatística............................................................................. 37

4 RESULTADOS E DISCUSSÃO............................................................. 40

4.1 Geração dos planos de informação .............................................................. 40

4.2 Geração do mapa de probabilidade de ocorrência........................................... 41

4.2.1 Seleção dos planos de maior importância ao estudo..................................... 41

4.2.2 Ponderação dos planos........................................................................... 49

4.2.3 Geração do mapa de probabilidade de visualização do cervídeo................. 49

4.2.4 Checagem dos resultados.................................................................. 53

4.2.4.1 Levantamento aéreo e terrestre........................................................ 53

4.2.4.2 Cruzamento do mapa de probabilidade de ocorrência, com os dados do levantamento aéreo.

4.2.4.3 Cruzamento do mapa de probabilidade de ocorrência, com os dados do levantamento terrestre....................................................................... 60

4.2.4.4 Possibilidades de emprego do SIG no Parque Nacional das Emas........ 63

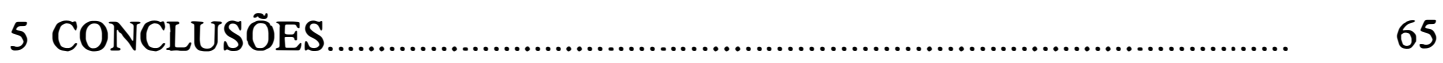

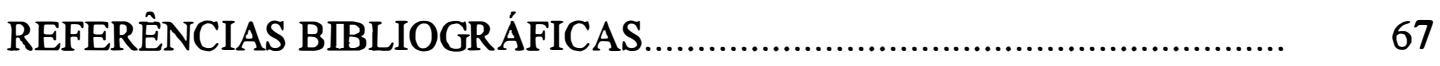


Página

1- Localização da área de estudo (IBDF/FBCN, 1981).

2- Imagem de satélite do Parque Nacional das Emas (PNE), cena WRS 224/073N+(29/07/88) do sensor TM do Landsat-5.Composição3(R), 4(G) e 5(B) (INPE).

3- Mapa hidrográfico do Parque Nacional das Emas (PNE).

4- Veado-campeiro (Ozotoceros bezoarticus): a-) Fêmea e macho em aceiro regenerado e b-) Macho em aceiro recém queimado.

5- a-)Visão sistemática do método de amostragem usando para levantamento do Veado-campeiro no Parque Nacional das Emas, b-) Visão do observador, com a vareta delimitando a área amostrada (Mauro, 1993)

6- Plano de informação "Aceiros".

7- Plano de informação "Hidrografia".

8- Plano de informação "Sedes de Fazendas".

9- Plano de informação "Campos".

10- Mapa de probabilidade de ocorrência do veado-campeiro no Parque Nacional das Emas, para a época seca do ano.

11- Mapa de probabilidade de ocorrência do veado-campeiro no Parque Nacional das Emas, reclassificado em três faixas de probabilidade. 
12- Superposição dos dados do levantamento aéreo, com o mapa de probabilidade de ocorrência, reclassificado em três faixas de probabilidade

13- Superposição dos dados do levantamento terrestre, com o mapa de probabilidade de ocorrência reclassificado. 
1- Escala utilizada na geração da matriz de comparação entre planos (Eastman et al.,1993)

2- Planos de informações gerados

3- Matriz de comparação.

4- Valor dos pesos de cada fator.

5- Distribuição dos animais, segundo o valor de pixels do mapa de probabilidade de ocorrência.

6- Histograma do cruzamento dos dados do levantamento aéreo, com a quantidade de pixels e seus devidos valores, em relação às faixas de distribuição do veadocampeiro.

7- Cruzamentos dos dados aéreos, por transecto, com o mapa contendo as faixas de probabilidade de ocorrência.

8- Comparação dos tratamentos 
USO DE UM SISTEMA DE INFORMAÇÕES GEOGRÁFICAS NA ANÁLISE DE DISTRIBUIÇÃO DO VEADO-CAMPEIRO (Ozotoceros bezoarticus) NO PARQUE NACIONAL DAS EMAS, GOIÁS.

\author{
Autora: NATÁLIA GONÇALVES FRUTUOSO \\ Orientador: Prof. Dr. CARLOS ALBERTO VETTORAZZI
}

RESUMO

A análise da distribuição de animais em seus habitats tem sido utilizada como uma opção viável no manejo de áreas silvestres. Este trabalho teve por objetivo mapear a distribuição do veado-campeiro (Ozotoceros bezoarticus), na época seca, em seu habitat natural, no Parque Nacional das Emas (PNE), em Goiás, determinando os lugares de maior probabilidade de ocorrência, por meio de um Sistema de Informações Geográficas (SIG).

$\mathrm{Na}$ elaboração do mapa de distribuição, foram considerados fatores ambientais naturais e antrópicos, bem como informações provenientes de observações de campo e da literatura existente sobre biologia e comportamento da espécie. Esses dados foram integrados em um ambiente SIG, adotando-se o procedimento de tomada de decisão por meio da avaliação multi-critérios/único objetivo. O mapa final obtido apresentou 3 (três) regiões diferenciadas em termos de probabilidade de ocorrência do animal (maior, média e menor) que foram checadas com a sobreposição dos dados de visualização aérea do veado-campeiro na área de estudo. A análise de variância não-paramétrica dos dados, por meio do teste de Kruskal-Wallis, mostrou diferença significativa ao nivel de $10 \%$, com valor de $\mathrm{P}=$ 0,0803 , tornando os resultados estatisticamente satisfatórios.

Pretende-se que este estudo seja de utilidade para a elaboração de futuros planos, visando à conservação e ao monitoramento do veado-campeiro, que se encontra em vias de extinção, devido principalmente às alterações produzidas em seu habitat natural pela ocupação humana. 


\title{
USE OF A GEOGRAPHIC INFORMATION SYSTEM IN THE ANALYSIS \\ OF THE PAMPAS-DEER (Ozotoceros bezoarticus) DISTRIBUTION IN THE EMAS NATIONAL PARK, GOIAS.
}

\author{
Author: NATÁLIA GONÇALVES FRUTUOSO \\ Adviser: Prof. Dr. CARLOS ALBERTO VETTORAZZI
}

\section{SUMMARY}

The analysis of the distribution of animals in their habitats has been used as a feasible option in the management of wild areas. This work had for objective to map the distribution of the pampas-deer (Ozotoceros bezoarticus), in the dry season, in its natural habitat, in the Emas National Park (PNE), in Goias State, Brazil, determining the places of larger occurrence probability, by means of a Geographic Information System (GIS).

In the elaboration of the map of distribution, either natural and anthropic environmental factors were considered, as well as information from field observations and from the existent literature on biology and behaviour of the species. Those data were integrated in a GIS environment, being adopted the procedure of decision making by means of the multi-criteria/single objective evaluation. The obtained final map presented 3 (three) areas differentiated in terms of occurrence probability of the animal (high, medium, and low probabilities) and it was checked with the overlay of data from aerial visualization of the pampas-deer in the study area. Non-parametric analysis of variance, through the Kruskal-Wallis test, showed a significant difference at the level of $10 \%$ among treatments, with $\mathrm{P}$ value $=0.0803$, making the results statistically satisfactories.

This study might be useful in the elaboration of future plans for the conservation and monitoring of pampas-deer, which is endangered, mainly due to the habitat alterations caused by humans. 


\section{INTRODUÇÃO}

Devido à rápida ocupação dos ambientes naturais que o mundo vem sofrendo, para atividades humanas, cresce cada vez mais a necessidade de se encontrar melhores formas de estudo para a conservação e manejo das áreas naturais restantes, com o intuito de ampliar o conhecimento sobre o ambiente que se deseja preservar, conservar, ou restaurar, encontrando-se assim, meios mais racionais de uso, que possivelmente venha amenizar o impacto humano (Firkowski, 1990). Deste modo, seguindo a tecnologia que avança ao longo dos anos, os estudos deverão tornar-se mais eficientes, ampliando os conhecimentos sobre a natureza e resultando em melhores formas de se manter a fauna e seu habitat.

No caso específico da fauna, em certas situações é possível encontrar-se respostas mais rápidas, objetivas e a custos baixos, para a sua conservação e manejo. Uma destas técnica é a que se utiliza de recursos de informática denominada Sistemas de Informações Geográficas (SIG), que são sistemas utilizados para armazenamento, processamento e visualização de dados diversos, referentes ao ambiente, transformandoos em produtos finais como mapas, gráficos e relatórios (Mclaren \& Braun,1993).

O SIG tornou-se um dos principais instrumentos disponiveis na atualidade para a análise do ambiente (Specht, 1996), podendo ser usados para a melhoria da condição da fauna (Miller,1994), que a cada ano vai perdendo seu habitat para o avanço da civilização humana, deixando de ocorrer na natureza, para existir apenas em zoológicos ou em outras instituições.

Levando em conta a grande importância da preservação da natureza, determinou-se testar, neste trabalho, a eficiência do SIG para as condições da fauna brasileira, tendo como objetivo principal, o estudo da distribuição do veado-campeiro. 
(Ozotoceros bezoarticus) em seu habitat natural (Parque Nacional das Emas, localizado no Estado de Goiás), para apresentação, em um mapa, das. regiões de diferentes probabilidades de ocorrência, para as condições de época seca do ano.

$O$ veado-campeiro foi indicado para este estudo devido as seguintes razões:

a-) Habitar áreas abertas;

b-) Apresentar porte que permite fácil visualização;

c-) A espécie encontra-se seriamente ameaçado, pela distribuição sistemática de seus habitat para a ocupação agropecuária, principalmente.

Quanto a determinação do local de trabalho o Parque Nacional das Emas foi escolhido por ser uma unidade representativa de campos cerrados (habitat natural do cervídeo em estudo) e por conter uma população significativa de veados-campeiros.

O emprego da tecnologia de geoprocessamento, além de poder-se tornar uma ferramenta muito útil para futuros trabalhos de monitoramento no Parque ou em outros locais onde a espécie se faz presente, poderá ser de grande utilidade para as demais espécies que ocorrem nesta unidade, bem como em outras, onde se necessita do monitoramento para a preservação da fauna local.

No que se refere a áreas particulares, com potencial de exploração do ecoturismo, o SIG poderá ser uma ferramenta muito útil para estudos da fauna local, no auxílio de sua preservação, monitoramento, juntamente com a coordenação dos passeios à região, facilitando assim a exploração racional desses locais. 


\section{REVISÃO DE LITERATURA}

\subsection{Análise da distribuição de animais}

A distribuição dos animais em relação ao ambiente é determinada pelas condições fisiológicas e estruturais que possuem, para se adaptarem ao impacto e influências que os fatores fisicos e biológicos do ambiente provocam sobre eles, induzindo-os a seleção natural e adequação a um habitat (Storer et al., 1989).

Todo organismo possui um limite de tolerância, máximo ou mínimo, para cada fator ambiental. Devido à isso, podemos afirmar que todos os seres possuem uma distribuição dinâmica, sujeita sempre a modificações, para driblar os fatores que afetam sua sobrevivência.

Os fatores físicos e biológicos proporcionados pelos ambientes que podem afetar a distribuição dos animais são muitos, como o clima, relevo, solo, hidrologia, ações antrópicas, vegetação, competição, predadores, doenças, pressão populacional, dentre outros. Todos estes fatores devem ser avaliados criteriosamente quando aplicados ao estudo da distribuição dos seres vivos.

Muitas metodologias são aplicadas para se retirar ou minimizar a subjetividade das análises de distribuição, para dar maior credibilid́ade aos resultados. Esses métodos foram aprimorados ao longo dos anos, com a criação de novas ferramentas que ajudam a esclarecer as atuais e complexas dúvidas sobre os mecanismos de adaptação.

Uma das principais técnicas que favorece o estudo da distribuição da fauna é o censo, que consiste na contagem (enumeração dos animais em uma determinada área) e na marcação dos locais de visualização, por exemplo por meio de GPS (para maior definição do local de observação). 
Alguns dos principais métodos que se utilizam do censo, de acordo com Brazo et al. (1994) e Silva (1996) são:

a-) Contagem direta da população;

b-) Método de captura e recaptura;

c-) Métodos de estudo de vestígios (pegadas, fezes, cheiros, sons ou marcas na vegetação) relacionados aos animais.

Muitas vezes é praticamente impossível realizar-se a varredura completa nas áreas de estudo e em todos os seus habitats. Nesses casos adota-se o emprego da amostragem para determinação das densidades populacionais e de seus habitats. Estas metodologias podem ser afetadas pela disposição espacial, pela variação temporal da população em estudo, pelos instrumentos que são utilizados, pelas pessoas envolvidas, pelo tipo de amostragem, pela natalidade e mortalidade da espécie.

Os métodos mais adequados ao estudo de cervídeos são geralmente técnicas convenientes para grandes mamíferos (Barnes \& Douglas-Hamilton, 1982), que abrangem:

a-) Contagem direta da população: que leva em conta o estudo da distribuição por mapeamento territorial, onde se tem o emprego de imagens de sensoriamento remoto, Sistemas de Informações Geográficas (SIG’s), censos aéreos e contagem por ajustamento.

b-) Métodos que levam em conta apenas a contagem de objetos e sinais relacionados com animais, que pode ser relacionada com a contagem direta.

\subsection{Levantamentos terrestres}

Em levantamentos terrestres, o mais comum é a utilização de transectos lineares, quando se quer obter informações sobre densidades e habitats dos animais em estudo. Sendo viável na redução de tempo e execução, é desfavorável em relação a áreas muito extensas (Silva, 1996). 
Nessa metodologia estima-se a população e as regiões de maior ocorrência através de amostragem sistemática, com distâncias de visualização e ambientes préestabelecidos, para a anotação dos indivíduos visualizados, habitats, horários (Eberhardt, 1978) e, se possível, vestígios como pêlos, fezes, cheiro etc., para uma maior adequação do objetivo a ser atingido (Brazo et al.,1994).

As falhas mais prováveis, em relação a este método, ocorrem, de acordo com Brazo et al.(1994), quando:

- não ocorre a contagem de animais, provocadas por visualizações confusas;

- há fuga do animal antes da visualização;

- a visibilidade é dificultada pela vegetação ou pelas condições meteorológicas;

- a estimativa de horário de movimentação do animal é errada;

- não há a familiaridade com a forma do animal;

- dentre outros fatores, dependendo de cada estudo.

Mesmo assim, o censo terrestre ainda é um dos mais clássicos levantamentos em campo para fauna.

\subsection{Levantamentos aéreos}

Os levantamentos aéreos têm sido usados há muito tempo para a pesquisa e manejo de vida silvestre, sendo recomendados quando se deseja estudar grandes vertebrados que habitam regiões abertas, de topografia plana e de fácil navegação (Swank et al., 1968) que sejam, como indicado por Mourão \& Magnusson (1997), animais conspícuos, de porte grande, com forma e cores destacadas, hábitos diurnos e que ocupem habitats de vegetação aberta, no caso terrestre, ou viverem em águas claras, para animais marinhos que freqüentam a superficie.

Uma das principais vantagens deste método é o de fornecer informações mais rápidas que o levantamento terrestre, além de fornecer uma visão panorâmica do local de estudo, favorecendo um maior conhecimento da área. 
Para esse tipo de levantamento, pode ser utilizado um pequeno avião de asas altas, ultraleve ou um helicóptero, como em Pinder (1997), para contagem de cervos-dopantanal (Blastocerus dichotomus) na região do rio Paraná. Na escolha da aeronave sempre devem ser levados em conta a geografia do local e o recurso financeiro disponivel para cobrir o custo da hora de vôo.

Os vôos podem ser realizados por meio do método de transectos, que são realizados por amostragem sistemática, onde são pré-estabelecidas as linhas de transectos a serem percorridas, a velocidade, o ângulo de visualização, a hora e o tempo de realização do vôo, com a anotação a cada visualização da espécie, o tipo de habitat em que se encontrava, as coordenadas do local de ocorrência, o horário, quantidade, sexo (se possível), entre outras características necessárias ao estudo, determinante para cada espécie que se deseja ter o levantamento (Mauro, 1993). Nesse caso, a área é percorrida apenas uma vez (admitindo-se que apenas uma fração da população pode ser detectada) (White et al., 1989).

Outro método utilizado é o de quadrantes, onde a área de estudo é percorrida mais de uma vez, podendo variar tanto a altura de vôo como a velocidade. Esse método é indicado para regiões montanhosas (Mourão \& Magnusson 1997). Nesta amostragem o procedimento de anotações a cada observação é similar ao indicado anteriormente.

Segundo Caughley (1980), em ambos os casos é impossível a contagem de $100 \%$ da população, sendo que o método por transectos é o mais recomendado por facilitar o emprego de fatores de correção e amenizar os custos do projeto.

Mas, como todo censo tende apenas a dar uma estimativa da contagem populacional no habitat, este método não foge à regra. As falhas que podem acontecer são: o ruído do avião (que afugenta os animais antes que o técnico os visualize); a forma como o animal reage ao visualizar a aeronave (escondendo-se ou imobilizando-se); a visibilidade não ser favorável devido ao tempo ou a vegetação; estimar-se a hora errada de movimentação da espécie; o pesquisador não estar familiarizado com a forma do animal; a altura do vôo e o cansaço do observador (Swank et al.,1968). 


\subsection{Levantamentos por sensoriamento remoto}

Para se ter uma abordagem mais clara sobre a área de estudo e fazer um planejamento mais adequado do levantamento, é importante ter-se em mãos, todas informações possíveis sobre o local de estudo (principalmente visuais). Isto pode ser obtido por sensoriamento remoto, que pode ser definido como a atividade que tem por objetivo obter informações sobre um objeto, área ou fenômeno, por meio da análise de dados coletadas por aparelhos denominados sensores, que não entram em contato direto com os alvos em estudo.

Dentre as faixas de radiação eletromagnética, a mais empregada é a do visível, onde se encontra a maior quantidade de equipamentos como câmaras fotográficas, sistemas eletro-ópticos acoplados a satélites (scanners), radares e radiômetros (Azevedo \& Verdesio, 1983).

Para estudos aplicados a fauna, geralmente se aplicam os produtos de fotografias aéreas e os gerados por sensores orbitais, como imagens de satélite (Porwal et al., 1996 e Mackinnon \& Wulf, 1994). A vantagem da fotografia aérea dá-se geralmente pela nitidez das formas registradas, que facilitam os estudos, quando se necessitam de maiores detalhes. Essa nitidez determina habitats, impactos humanos, uso da terra, censo e outras dados necessários para estudo (Anderson et al., 1987).

Outra forma de se obter informações sobre ambiente, principalmente em áreas muito extensas, facilitando o seu mapeamento, é a utilização de imagens geradas por sensores orbitais (Hall, 1994). Nesta técnica há o registo das dimensões, características fisiográficas e impacto humano, tanto dentro como fora dos limites da área de trabalho, para estudo de fauna.

Muitos trabalhos utilizam-se deste sistema como ferramenta de estudo: Palmeirim (1988) mapeou os habitats de aves em Kansas, EUA; Green et al. (1987) determinaram padrões de distribuição de habitat de aves no México; e Hill \& Kelly (1987) mapearam o habitat de cangurus na Austrália para censo aéreo.

Estes registros são realizados por meio de sensores orbitais, que medem a radiação emitida ou refletida pelos corpos e organiza esses dados em um conjunto de 
pontos (pixels) em linhas paralelas, compondo assim uma imagem. Além disso, eles podem registrar, simultaneamente, o mesmo ponto em vários comprimentos de onda da energia radiante. Dessa maneira são obtidas informações multiespectrais de grande valia na identificação de alvos. Os scanners podem registrar a radiação eletromagnética desde o violeta $(0,3 \mu \mathrm{m})$ ao infravermelho termal ( $1 \mathrm{~mm}$ de comprimento de onda) (Azevedo \& Verdesio, 1983).

Estas imagens são gravadas em fitas originais com 256 níveis de cinza (8 bits) e como os computadores podem distinguir todos os 256 níveis de cinza, amplia-se em muito a capacidade de interpretação. Este tipo de interpretação pode ser chamada de automática ou digital, para distingui-la da visual direta .

Assim, quando se necessita de um detalhamento maior, utilizam-se fotografias aéreas, e quando se necessita de uma visão mais ampla do ambiente, usam-se imagens de satélites. Utilizando-se as duas fontes, os resultados serão os melhores, pois conta-se com o sinergismo decorrente dessa utilização conjunta.

\subsection{Emprego de Sistema de Informações Geográficas (SIG)}

O SIG é uma importante ferramenta para o armazenamento, visualização e processamento de dados diversos, referentes ao ambiente, para transformá-los em produtos finais como mapas, gráficos e relatórios (Mclaren \& Braun, 1993).

Como é necessário, em estudos ambientais, criar um sistema que possa armazenar e a qualquer momento, recuperar e cruzar os dados arquivados, o SIG se tornou uma técnica de grande utilidade, pois ele permite a facilidade no manuseio de grandes quantidades de informações de diversas fontes, com diferentes níveis de detalhamento e de diferentes temas.

Assim tem sido aplicado como ferramenta pelos planejadores e se tornou uma das técnicas mais poderosas que encontramos hoje na análise do ambiente (Specht, 1996) e que pode ser usada para a melhoria da condição da fauna (Miller, 1994), que a cada ano vai perdendo seu habitat para o avanço da civilização humana, deixando de ocorrer na natureza, para existir apenas em zoológicos ou em outras instituições. 
Os SIGs são dotados essencialmente de três etapas que são decisivas e importantes, estando intimamente ligadas entre si, de uma maneira tal, que o sucesso do resultado final vai depender das rotinas que deverão ser cumpridas de modo a criar um arquivo consistente de dados.

$\left.1^{9}\right)$ Entrada de dados

Para se ter uma eficiência na análise do SIG, deve-se gerar um banco de dados com informações viáveis, confiáveis e com qualidade. As fontes destes dados podem ser fotografias aéreas, gráficos, cartas planialtimétricas, imagens de satélites, informações literárias, que podem entram no sistema via scanner, digitalização, teclado ou diretamente como imagens digitais (Vettorazzi, 1992).

No sistema os dados poderão ser representados nos formatos raster ou vetorial (Eastman, 1992). O formato raster (ou matricial) é composto por uma matriz de células denominadas pixels, com valores específicos atribuídos a cada unidade.

O formato vetorial é composto por um conjunto de pontos, com pares de coordenadas cartesianas definidas, $\mathrm{x}$ e y, que vão formar os pontos, linhas e polígonos. Numa representação vetorial é necessário levar-se em conta certas propriedades topológicas, que são unidades elementares de qualquer representação bidimensional, a saber (Soares, 1994).

a-) Ponto: ente caracterizado por um par de coordenadas $x$ e y que, quando dispostos sucessivamente, podem formar uma "linha";

b-) Nó: ponto inicial e/ou final, ao qual está associada uma feição topológica;

c-) Arco: conjunto de pontos, determinando um linha, delimitada por dois nós, um inicial e um final;

d-) Polígono: região limitada por uma sucessão de arcos, na qual há mudanças de feição topológica, com um ponto inicial e um ponto final. 
$2^{-}$) Armazenamento e manipulação

O armazenamento deve possuir uma estrutura e organização de dados eficientes, para que se possa acessá-los de uma forma rápida, por acasião da manipulação e atualização dos mesmos, para se atingir os objetivos necessários (Soares, 1994). Esses dados podem ser armazenados nas formas raster, vetorial ou alfanumérica (Vettorazzi, 1992).

\section{3º) Recuperação, análise e saída}

Esta etapa é uma parte da ferramenta SIG, com um conjunto de funções específicas de acordo com a finalidade para a qual o mesmo foi projetado. A eficiência das análises será em função do formato do armazenamento, estrutura de organização dos dados na base e do tamanho das unidades de recuperação, conforme Soares (1994).

A saída de dados, em geral resultados das análises, pode ser dar sob as formas de mapas, gráficos, tabelas etc.

Assim, com base nestas capacidades, March \& Midence (1989) descrevem que o SIG pode ser aplicado aos seguintes estudos, envolvendo fauna:

a-) $\mathrm{Na}$ análise e avaliação de habitats para populações silvestres;

- Descrição de características de habitat;

- Monitoramento da dinâmica do habitat;

- Utilização e avaliação das unidades ecológicas, com base em critérios distintos;

b-) Práticas de reintrodução, translocação e repovoamento;

c-) Proteção e restauração de áreas silvestres protegidas;

d-) Estudos biogeográficos e de espécies migratórias;

e-) Estudos locais e regionais sobre a dispersão de espécies que sejam nocivas ao homem;

f-) Estratégias e medidas de planejamento para a proteção da fauna silvestre;

g-) Censos de populações e estudos ecológicos; 
h-) Estudos de impacto ambiental sobre a fauna silvestre por atividade humana;

i-) Estratégias de proteção de áreas de habitat, com forte pressão de fragmentação.

No emprego do SIG no estudo da distribuição e habitats da fauna, há várias situações em que seu uso é muito favorável, como na necessidade de mapear vários animais, em áreas extensas, relacionando a fauna local e seu habitat (com vários fatores ambientais interagindo), para criação de unidades de prioridade de conservação (Bojórquez-Tapia et al., 1995) no México; Worah et al.(1989), que demarcaram áreas de potencial de habitat para vida silvestre na Índia; Miller \& Allen (1994), que mapearam espécies raras em Madagascar; Scott et al. (1993), em estudos de biodiversidade, nos EUA; Aspinall \& Veitch (1993), que delimitaram habitat de aves na Escócia; e no Brasil, o Ministério do Meio Ambiente e Recursos Hídricos e o da Amazônia Legal, juntamente com as Universidades de Brasília, Federal de Minas Gerais e Federal de Pernambuco, mapearam com uso do SIG Arc/Info, unidades prioritárias de conservação da Biodiversidade da Mata Atlântica do Nordeste (Ministério do Meio Ambiente, 1993).

Em muitos casos o estudo se aplica apenas a uma espécie, como Mladenoff et al. (1995), que determinaram áreas prioritárias para sobrevivência de lobos (Canis lupus lycaon), em regiões de Michigan (EUA), para onde foram translocados. No Norte da Califórnia, Congalton et al. (1993) descreveram a distribuição e habitats adequados a veados (Odocoileus hemionus) e determinaram pré-requisitos para o manejo dos mesmos, com uso de SIG. Peterson (1996), com a ajuda de GPS e de SIG, monitorou o urso-pardo (Ursus arctos) em Montana, EUA.

Estes trabalhos são auxiliados muitas vezes com a aplicação de banco de dados, contendo coordenadas de locais de observação das espécies, diretamente sobre os mapas de fatores ambientais, para se estimar os locais de maior ocorrência. Como em Agee et al.(1989), que por meio de dados de observação nos locais de ocorrência, associados com determinados tipos vegetativos, determinou por meio do SIG as áreas de habitat do urso-pardo (Ursus arctos), no Estado de Washington, EUA.

No Alasca, o SIG foi utilizado para analisar dados de telemetria, para determinar os limites das áreas de vida do veado-de-cauda-preta (Odocoileus hemionus) 
(Chang et al.,1995) e, no Brasil, Mauro (1993), por meio de censos aéreos e geoprocessamento, mapeou o habitat do cervo-do-pantanal (Blastocerus dichotomus) no Pantanal Matogrossense.

Atualmente a EMBRAPA ${ }^{1}$ está elaborando um novo levantamento censitário na região do Pantanal, com veado-campeiro (Ozotoceros bezoarticus), cervo-dopantanal (Blastocerus dichotomus), ninhos de tuiuiú (Jabiru mycteria), capivara (Hydrochoerus hydrochoeris) e jacaré (Caiman crocodilus yacare), para posterior criação de mapas de habitat com o Idrisi, que é um dos mais difundidos softwares de sistema de informações geográficas.

Algumas vezes o SIG é utilizado como ferramenta para estudo de caso. Como por exemplo em Michelmore (1994), que determinou a possível distribuição do elefanteafricano (Loxodonta africana) na África, para auxiliar em sua conservação.

Há momentos que apenas uma característica ambiental, como o clima, pode descrever a distribuição da espécie em estudo, como em Walker (1990), na Austrália, que por meio da temperatura conseguiu mapear a distribuição de cangurus (Macropus ssp), ou como em Aspinall \& Matthews (1994), que analisaram o impacto climático sobre a distribuição e abundância da fauna silvestre.

0 critério do pesquisador de selecionar a melhor maneira de se realizar as análises terá como base principal as informações em que ele tem acesso e o objetivo que queira atingir. Em todos os casos, a estatística é uma ferramenta auxiliar que, associada ao SIG, traz resultados viáveis para se atingir os objetivos dos estudos, como em Clark et al., (1993), que usaram modelos multivariados e SIG para determinar habitats de maior pontencialidade para fềmeas de urso-preto (Ursus americanus); Knick \& Dyer (1997), que determinaram com SIG a distribuição de habitats do coelho-de-rabo-preto (Lepus californicus) com o auxílio de modelos multivariados de habitats e Manen \& Pelton (1997), que usaram SIG e análise estatística para se determinar o uso do habitat do urso-preto (Ursus americamus).

\footnotetext{
${ }^{1}$ Comunicação pessoal, com pesquisadores envolvidos no projeto.
} 


\section{MATERIAL E MÉTODOS}

\subsection{Material}

\subsection{1 Área de estudo}

\subsubsection{Enquadramento fisiográfico}

O Parque Nacional das Emas (PNE) situa-se no Planalto Central do Brasil, no município de Mineiros, sudoeste do Estado de Goiás, aproximadamente entre as latitudes $17^{\circ} 50^{\prime} \mathrm{S}$ e $18^{\circ} 23^{\prime} \mathrm{S}$, e as longitudes $52^{\circ} 43^{\prime} \mathrm{W}$ e $53^{\circ} 09^{\prime} \mathrm{W}$. Sua área é de 131.868 hectares (Figura 1), sendo considerada a unidade de conservação de maior representatividade do cerrado, principalmente de campos.

Esta localizado entre as bacias do rio da Prata e do Amazonas, no flanco oriental do Planalto Central, sendo limitado ao norte e nordeste pelo Rio Jacuba, noroeste e oeste pela BR-358 (trecho Baús-Mineiros), sudoeste pelo córrego Cabeceiraalta, que deságua no Rio Formoso, sudeste por fazendas agrícolas e sul por estrada de terra, que vai até a cidade de Chapadão do Céu, situada a $35 \mathrm{~km}$ do Parque.

No entorno do Parque, o uso da terra é composto principalmente pela agricultura mecanizada de extensas áreas, onde a cultura de soja prevalece. Apenas as fazendas que fazem divisa na região sudeste do Parque cultivam milho. Ao noroeste (em uma faixa de 500 metros, em média, que começa a partir do Rio Jacuba), a pecuária ocorre, mas ultrapassando esta faixa a cultura de soja volta a dominar. Na figura 2 podem ser observadas as áreas do Parque e de seu entorno, tal como aparecem na imagem de satélite Landsat-5 (sensor TM, composição 3/4/5).

Quanto à altitude, a variação é de $650 \mathrm{~m}$ a 1.000 m (IBDF/FBCN, 1981). 


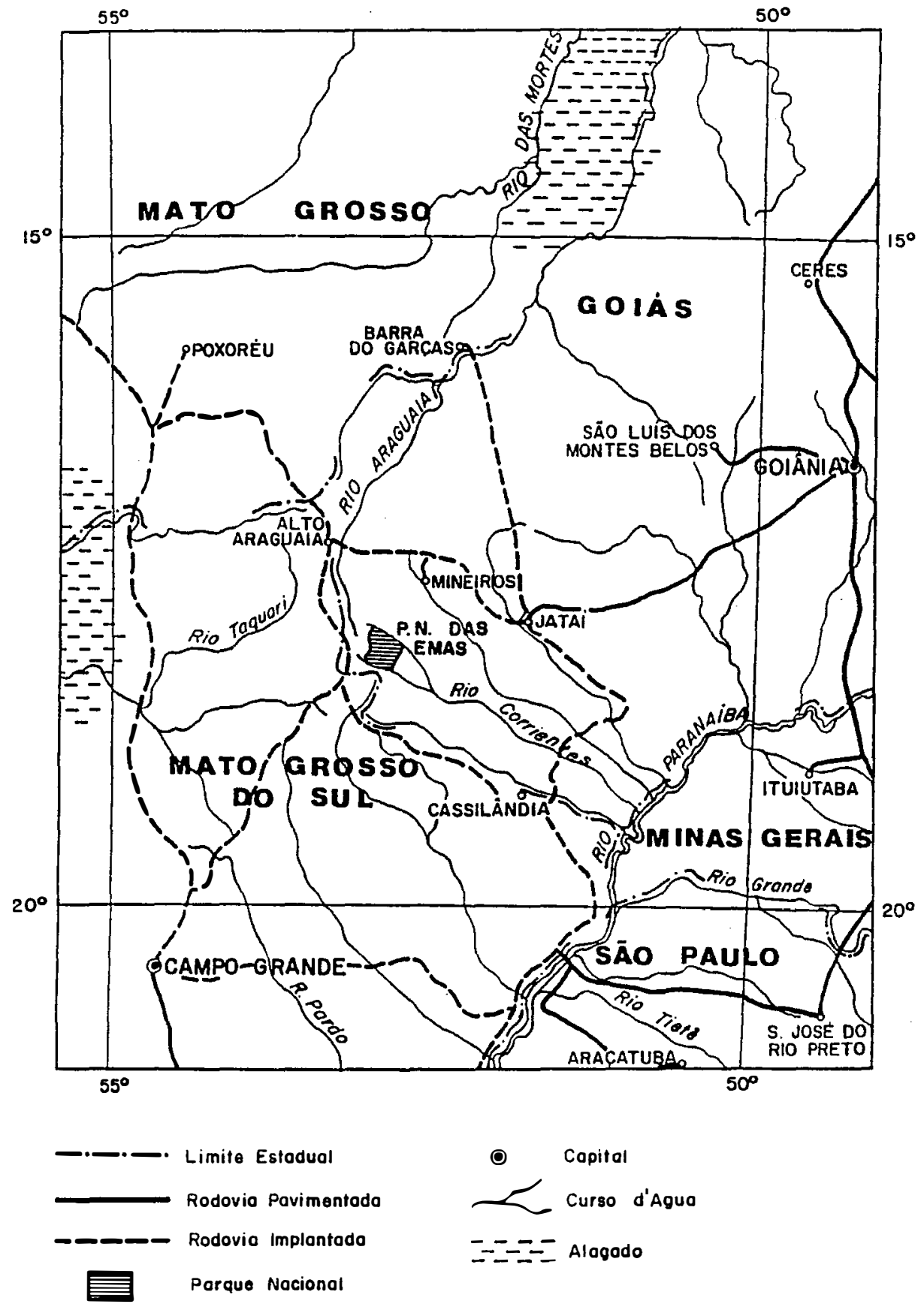

Figura 1 - Localização da área de estudo (IBDF/FBCN, 1981). 


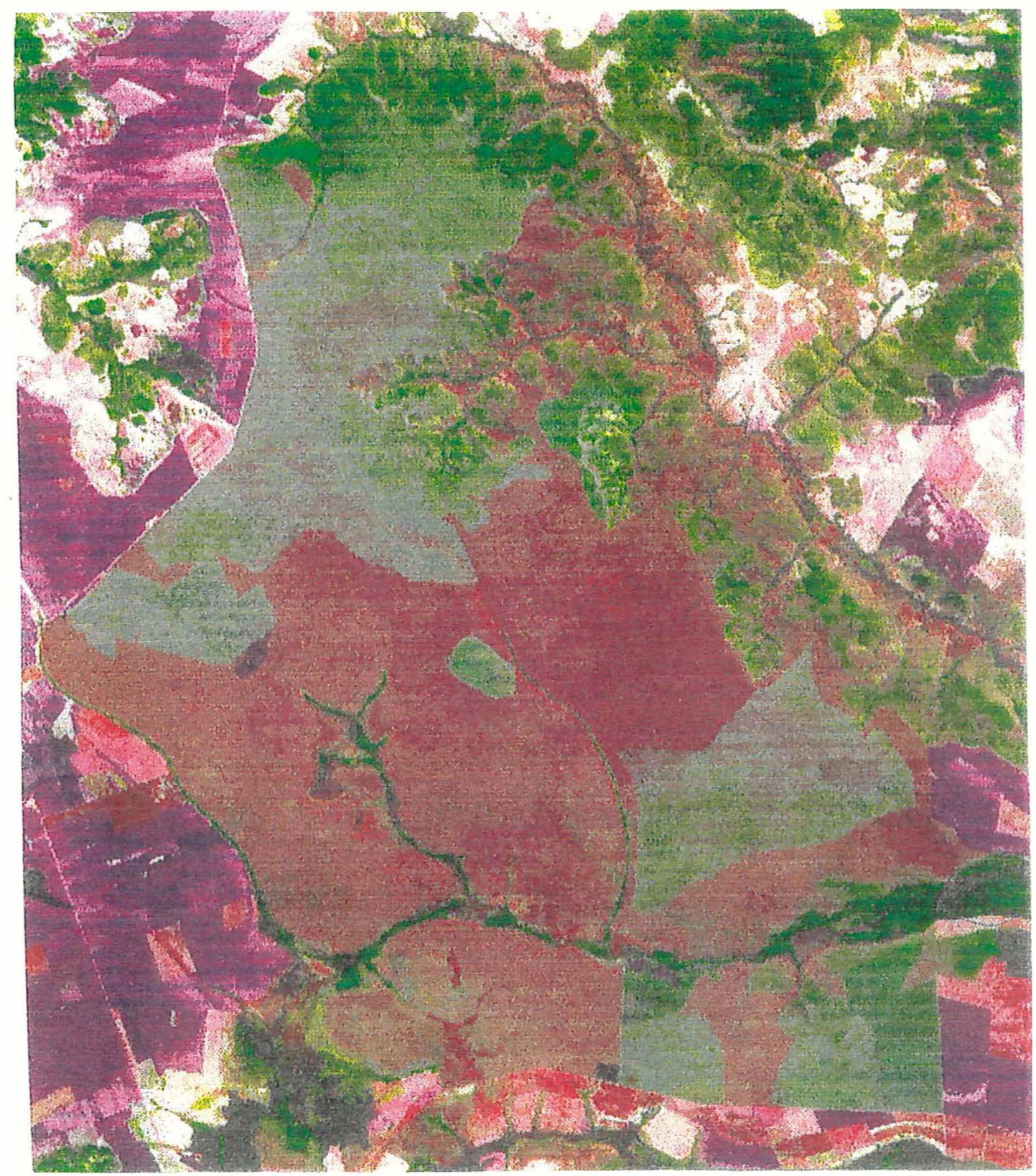

Figura 2 - Imagem de satélite do Parque Nacional das Emas (PNE), cena WRS 224/073N+ (29/07/88), do sensor TM do Landsat-5. Composição 3(R), 4(G) e 5(B) (INPE). 


\subsubsection{Clima}

No inverno o clima é basicamente seco, mas devido à continentalidade da região há registros freqüentes de temperaturas muito baixas, estando o local sujeito a fortes geadas que ressecam de $80 \%$ a $90 \%$ da folhagem dos campos e das matas. Entretanto, neste mesmo inverno seco, também ocorrem temperaturas elevadas, o que aumenta o risco de grandes incêndios. No verão, a estação é de muita chuva e de temperaturas altas, com precipitações na média de $1.500 \mathrm{~mm}$ (IBDF/FBCN, 1981).

\subsubsection{Hidrografia}

Os rios principais do Parque são o Formoso e o Jacuba (Figura 3), que se unem fora do Parque (a sudeste), para formarem o rio Correntes, que é afluente do rio Parnaiba, um dos tributários da Bacia do Prata.

O Rio Formoso corre no sentido de oeste-leste e possui como cabeceira mestra o córrego Cabeceira-alta, que recebe dois afluentes pela margem direita: o Córrego Cupim, que possui os tributários, Córrego Gabiroba, Rego d'água, Gloria e Sucurizinho, que quando se encontra com o segundo afluente, o Córrego Cabeceirão, torna-se o Rio Formoso, que ainda recebe pela margem esquerda os Córregos da Lagoa e Buriti Torto.

O Rio Jacuba, que corre no sentido sudoeste, tem sua cabeceira mestra no extremo norte do Parque. Ele recebe vários córregos: Jacubinha, Avoador, do Coxo, Bandeira, Furna grande, Água Ruim, Areias, Ribeirãozinho, e outros sem denominações. O Jacuba drena $40 \%$ da área restante e possui vales mais profundos e largos do que os do Formoso.

Certos trechos dos rios, durante a estação chuvosa, são expandidos consideravelmente. Estas áreas inundáveis (campos úmidos e varjões), durante o período de seca permanecem com o lençol freático quase ao nível do solo, sendo mais freqüentes no Rio Formoso. Devido a esta particularidade, tornam-se locais de vital importância para a fauna. 


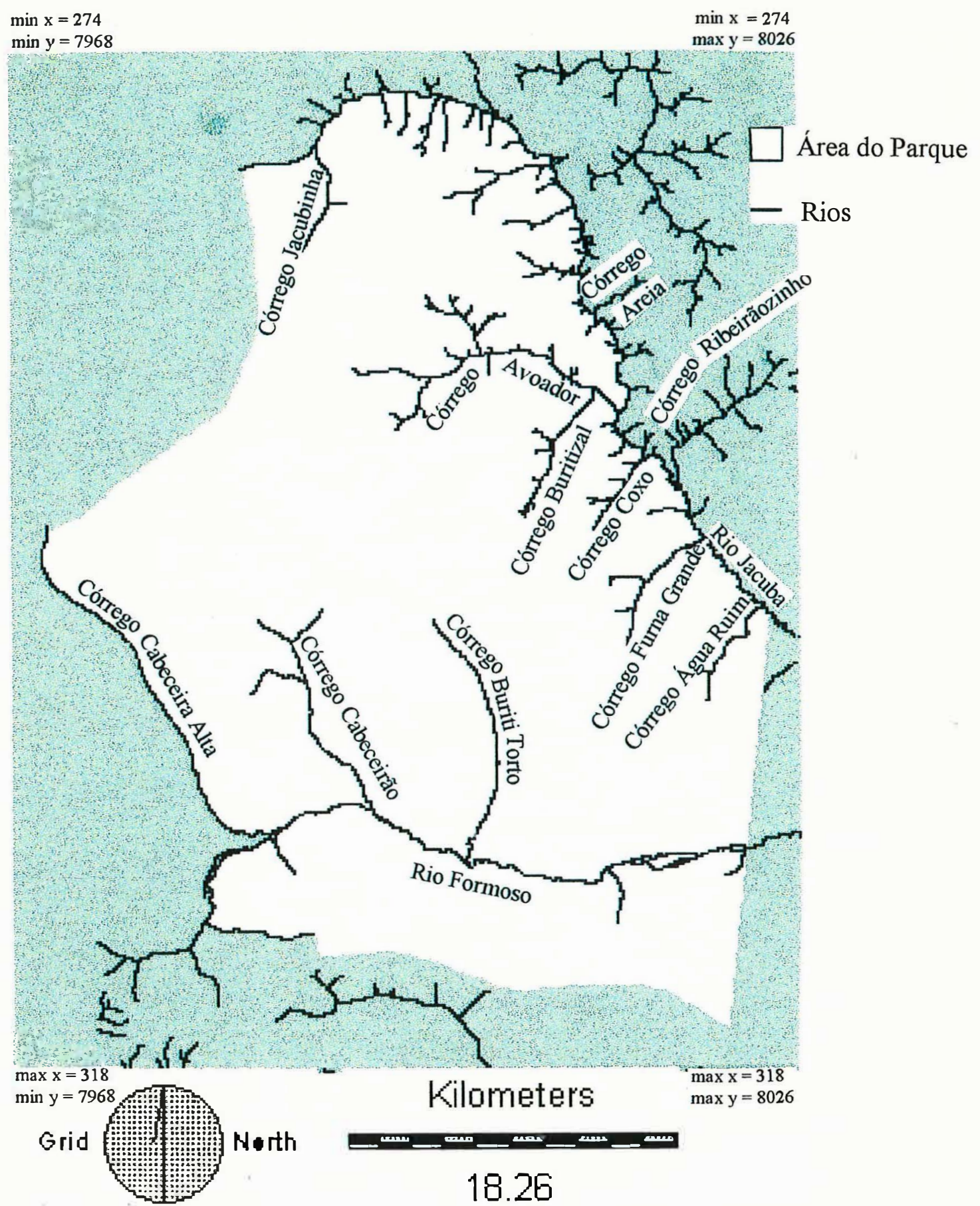

Figura 3 - Mapa hidrológico do Parque Nacional das Emas (PNE). 
A principal importância do Formoso são suas áreas inundáveis e seus campos úmidos. Já o Jacuba tem nos seus vales mais escavados sua maior significância, por apresentarem um solo praticamente sem déficit de água durante todo o ano, sendo um ótimo local para abrigo e obtenção de alimentos por parte dos animais, principalmente nas estações secas.

Os rios do Parque Nacional das Emas são oligotróficos, ou seja, pobres em nutrientes minerais. Este fato é geologicamente fácil de ser explicado, pois a área é muito velha, apresentando um alto grau de lavagem. O teor de íons nas águas é baixíssimo, o mesmo ocorrendo com a matéria orgânica. As águas são cristalinas com reflexo azulado (IBDF/FBCN, 1981).

\subsubsection{Solos}

A predominância no Parque é de solos latossólicos amarelo-avermelhados e vermelho-amarelados. Nas calhas dos rios há a concentração de aluviões, solo litólicos com formação de solos hidromórficos.

Como o solo é o principal modelador da vegetação do cerrado, constata-se uma variação de alternância, do solo mais rico ao mais pobre. Assim existe mata mesofitica de interflúvio no solo mais rico e, conforme a diminuição de nutrientes, são encontrados cerradão, cerrado, campo de cerrado, campo sujo e, por último, campo limpo, no solo mais pobre (sendo os campos limpo e sujo os de maior tendência a pegar fogo em relação aos demais ambientes) (IBDF/FBCN, 1981).

\subsubsection{Vegetação}

Estando o Parque Nacional das Emas localizado na área nuclear da província ou região dos Cerrados, a vegetação que lá ocorre é representativa sob os aspectos fisionômicos e florísticos (como era de se esperar). $\mathrm{O}$ mais importante, porém, é que sua vegetação encontra-se muito pouco degradada, sendo considerada a melhor área preservada de cerrado no Brasil (IBDF/FBCN, 1981). 
Os habitats encontrados no Parque formam um ecossistema dinâmico, o qual é representado por sua composição vegetativa específica de $60 \%$ por campos limpos e campos sujos e os restantes $40 \%$ cobertos por outras formas fisionômicas de cerrado: campos cerrado, cerrado "strictu sensu", matas ciliares, veredas, campo de murunduns e pequenas manchas de mata mesófila de interflúvio (Coutinho, 1990a e 1991).

Os cursos d'água que cortam os cerrados do Parque têm em geral uma mata ciliar (mata ou floresta de galeria) ao seu redor, sendo que nas nascentes, é comum a formação de veredas que se mesclam com a mata ciliar ou, em alguns casos, se alternam rio abaixo. Entre a mata ciliar e o cerrado, na grande maioria dos casos, existe um campo úmido ou um campo de murunduns que podem ocorrer em cabeceiras e ao longo dos vales, com alto índice de umidade.

A origem dos cerrados é ainda inexplicável. Alguns cientistas acreditam que os cerrados brasileiros são produtos de mudanças macroclimáticas; outros postulam que os cerrados são um tipo de vegetação clímax resistente ao fogo; e outras linhas de pensamento, defendem a teoria que a distribuição do cerrado é controlada pelo solo de origem geológica de baixa fertilidade, apresentando alta acidez (Goodland \& Ferri 1979 e IBDF/FBCN, 1981). Mas, a grande maioria dos autores concordam que o cerrado é um tipo de vegetação bastante antiga e que cedeu terreno ante a expansão da Floresta Amazônica e da Floresta Atlântica, ficando assim com manchas incrustadas de outras formas de vegetação.

As principais características dos tipos de vegetação que se encontram no Parque são apresentados a seguir:

Mata Ciliar: Vegetação típica de beira de rios, córregos e riachos, localizada no fundo dos vales. Árvores do grupo das dictoledôneas são as espécies dominantes, podendo também conter palmeiras. A vegetação é sempre verde e, às vezes, está sobre solo constantemente encharcado. Não apresenta caducifolia na estação seca e sua altura média do estrato arbóreo está entre $20 \mathrm{~m}$ a $30 \mathrm{~m}$. Quando esta vegetação apresenta porte menor é comumente chamada de mata de pindaíba (IBDF/FBCN, 1981). 
Campo Úmido: Ocorre entre a mata ciliar e o cerrado. Sua largura pode variar de alguns até dezenas de metros, aparecendo, também, nas nascentes dos cursos d'água. No campo úmido o lençol freático aproxima-se e permanece perto da superfície durante parte do ano ou a água pode aflorar na parte inferior da encosta e correr em película fina sobre a superficie. Sua flora é basicamente de gramíneas e ciperáceas, ocorrendo a taboa (Typha sp) e pequenos arbustos de Ludwigia sp. (IBDF/FBCN, 1981).

Campo de Murunduns: Na realidade o campo de murunduns é uma transição entre o campo úmido e o cerrado. Estes montículos circulares, com alguns metros de diâmetro e mais ou menos cinqüenta centímetros de altura, encontram-se espalhados pelos campos úmidos. Por serem bem drenados, apresentam a flora do cerrado, como se fossem "ilhas" de cerrado no campo úmido.

No Pantanal são criados por cupinzeiros (Oliveira-Filho \& Furley, 1990) e sua origem no Parque Nacional das Emas é incerto. Segundo Coutinho ${ }^{2}$ (1996), podem ser formados por erosão diferencial, na enchente, que ao erodir o solo, transforma estas regiões em campo de murunduns.

Vereda: Formação vegetal composta por buriti (Mauritia flexuosa). Ocorre em solos permanentemente saturados, na mata ciliar ou principalmente nas cabeceiras. Pode ter algumas dicoteledôneas associadas, tendo o solo uma cobertura graminosa.

Mata Mesofítica de Interflúvio: Este tipo de vegetação ocorre nos interflúvios, em pequenas áreas de latossolos mais férteis, derivados de rochas alcalinas como basalto e gabro ou de certos tipos de gnaisse e de micaxistos. Caracteriza-se por vários graus de caducifolia, durante a estação seca, o que contribui para o aumento da matéria orgânica no solo e sua altura média do estrato arbóreo de $15 \mathrm{~m}$ a $20 \mathrm{~m}$.

${ }^{2}$ COUTINHO, L.M. Comunicação pessoal, 1996. 
Campo Limpo: As gramíneas são as plantas dominantes. Há também ervas e pequenos arbustos, sendo que não existem plantas lenhosas. Alguns campos limpos do Parque apresentam gramíneas com $1,50 \mathrm{~m}$ de altura e a espécie mais alta é o capim flecha (Tristachya leiostachya) que, quando floresce, aumenta muito a fitomassa do Parque, criando maior probabilidade de queimadas na estação seca principalmente, quando as florescências secam.

Nos campos limpos onde a cobertura de gramíneas é mais baixa e aberta há grande quantidade de arbustos e ervas, alguns frutíferos e de interesse alimentar para a fauna. Os mais freqüentes são fruta-de-ema (Parinari $s p$ ), caju (Anacardium sp), gabiroba (Myrcia sp e Campomanesia sp), murici (Byrsonima sp) e annonaceae (várias espécies). (IBDF/FBCN, 1981).

Campo sujo: Semelhante ao anterior, porém, com arbustos lenhosos esparsos, com altura inferior a $3 \mathrm{~m}$, apresentando geralmente uma densa cobertura de gramíneas. Existem áreas de campo limpo e campo sujo onde a espécie dominante é uma palmeira de caule subterrâneo, o Indaiá (Attalea $s p$ ), e outras áreas de campo sujo, cuja espécie dominante são arbustos do gênero Roupala.

Campo Cerrado: Árvores com alturas superiores a $3 \mathrm{~m} \mathrm{e}$ em maior densidade que o anterior, com uma cobertura inferior a $10 \%$, podendo ocorrer uma alta densidade de arbustos ou, quando menos densos, uma maior cobertura de gramíneas.

Cerrado "Strictu Senso": A altura média das árvores é em torno de $7 \mathrm{~m}$, com dossel aberto (10-60\% de cobertura), sub-bosque arbustivo, aberto, esparso ou mesmo ausente.

Cerradão: Esta é a formação mais alta, com árvores variando entre $7 \mathrm{~m}$ a $15 \mathrm{~m}$ podendo, excepcionalmente, atingir $20 \mathrm{~m}$, apresentando um dossel com 30-60\% de cobertura nas formas mais abertas e acima de $60 \%$ nas mais fechadas. No Parque não se encontra em grande quantidade. 


\subsubsection{Fogo}

O fogo, natural ou provocado, desempenha um dos principais papéis em relação aos cerrados, alterando continuamente sua aparência e possivelmente a distribuição dos animais. Depois da ocorrência da queimada, muitas espécies rebrotam e florescem imediatamente, sendo o fogo, em muitos casos, o fator que induz o florescimento de muitas espécies, pois a parte seca da planta evita esse fenômeno, mesmo o crescimento.

Nos locais onde ocorrem queimadas, a variedade de espécies vegetativas é maior (IBDF/FBCN, 1981), tornando-se regiões de grande atração da fauna, devido à rica oferta alimentar (Coutinho, 1990b).

Sabe-se atualmente que o fogo tem certa importância na manutenção das formas mais abertas de cerrado. Convém ressaltar que onde estas formas ocorrem naturalmente, isto é, sem interferência humana, estão relacionadas a três fatores: esterilidade (acidez elevada), pouca profundidade do solo e má drenagem.

Com certeza, algumas áreas de cerrado do Parque Nacional das Emas, mesmo protegidas contra o fogo, continuarão com seu "status" atual, em função do solo que lhe serve de substrato.(IBDF/FBCN, 1981).

O solo, além de ser o principal fator de determinação do tipo de vegetação, é também, em muitos casos, o protetor de algumas espécie vegetativas, pois sua superficie age como um perfeito isolante térmico, que evita que as plantas morram, na queimada.

$\mathrm{Na}$ constituição química do solo, o alumínio que fica na camada superficial, desaparece por aproximadamente 40 dias, após a queimada. Sendo enriquecido posteriormente pelas cinzas, que são uma fonte preciosa de nutrientes, constituídas de cálcio $(\mathrm{Ca})$, potássio $(\mathrm{K})$, magnésio $(\mathrm{Mg})$ entre outros elementos, que estáriam também passando de um estrato vegetativo para outro. Deve ser lembrado que, após 20 a 60 dias, o enriquecimento superficial desaparece. (Coutinho, 1990b).

Mas nem todos os nutrientes vão obrigatoriamente para a superficie do solo, sob a forma de cinzas (Coutinho, 1990b). Quase todo o nitrogênio (N) e praticamente a metade do fósforo $(\mathrm{P})$, do potássio $(\mathrm{K})$, do cálcio $(\mathrm{Ca})$, do magnésio $(\mathrm{Mg})$ e do enxofre 
(S) são transferidos da biomassa para a atmosfera e acabam voltando ao solo pela ação da gravidade ou da chuva, com total retorno por volta de três anos. Assim, se as queimadas forem realizadas em menos de três anos, poderá haver esgotamento do ecossistema.

No Parque Nacional das Emas, devido ao grande acúmulo de fitomassa acumulada durante $o$ ano, principalmente pela grande quantidade de capim-flecha (Tristachya leiostachya), ocorrem incêndios em grandes escalas, que podem ser naturais (por raios, principalmente ${ }^{3}$ ) ou provocados (ponta de cigarro ou vindo de fora dos limites do Parque, das fazendas do entorno, principalmente na época de colheita de soja, quando são provocadas grande queimadas nas plantações). Já ocorreram grandes incêndios no Parque, como em 1988, quando foi queimado $60 \%$, e o maior de todos em 1994, que atingiu $98 \%$ do Parque.

Desde o plano diretor de 1981, foi proposto um programa de controle de incêndios, por meio do sistema de aceiros, que tem a função de barrar o fogo. Muitas vêzes eles não foram queimados, devido à falta de verba, o que favoreceu os grandes incêndios citados. Estes aceiros são feitos paralelamente às estradas que percorrem o Parque, voltados para cursos d'água, para se evitar que o fogo se espalhe no Parque, caso escape durante o manejo do fogo.

Suas queimas devem ser feitas todos os anos (quando há recurso financeiro) na época seca, no mês de junho geralmente, sempre com o auxílio de bombeiros. Nessa época há um índice muito grande de ventos, que ocorrem principalmente no período das 10:00 h ao final da tarde. Assim os trabalhos são realizadas no período noturno, para se evitar que o fogo se espalhe além dos limites dos aceiros.

Eles se dividem em três categorias, quanto à largura:

a-) De 25 m - Localizados em campos sujos;

b-) De $40 \mathrm{~m}$ - Que ocorrem paralelos à cerca, descendo o Rio Jacuba até o Córrego Glória, seguindo o limite oeste e paralelos à cabeceira mestra do Jacuba;

\footnotetext{
${ }^{3}$ É uma região de grande ocorrência de raios, segundo informações obtidas no local.
} 
c-) De $60 \mathrm{~m}$ - Localizados desde a nascente do Jacuba e que seguem pela parte mais elevada do divisor entre a drenagem do Jacuba e do Formoso.

\subsubsection{Fauna}

O Parque é riquíssimo em fauna, abrigando muitas espécies em extinção (IBDF/FBCN, 1981) que são facilmente observadas (Redford, 1987).

A fauna do cerrado e das matas dos vales está adaptada, seja em densidade ou diversidade de espécies, aos estratos produtivos, sendo a fauna que se utiliza do primeiro estrato, a mais variada e que contribui com alta porcentagem para o total de biomassa do ecossistema do Parque Nacional das Emas.

A estimativa, até o período atual, é de aproximadamente 34 espécies de mamíferos por Redford (1983), 250 espécies de aves, inúmeras espécies de lagartos, cobras e artrópodes, pelo IBDF/FBCN (1981).

Dentre os animais que ocorrem no Parque, podem ser citados:

MAMÍFEROS ${ }^{4}$ :veado-campeiro (Ozotoceros bezoarticus), tamanduábandeira (Myrmecophaga tridactyla), tamanduá-mirim (Tamandua tetradactyla), loboguará (Chrysocyon brachyurus), queixada (Tayassu pecari), cateto (Pecari tajacu), onça-pintada (Panthera onca), onça-parda (Puma concolor), tatu-canastra (Priodontes moximus), tatu-de-rabo-mole (Cabassous unicinctus), tatu-peba (Euphractus sexcinctus), tatu-galinha (Dasypus novemcinctus) cangambá ou jaritataca (Conepatus semistriatus), raposinha-do-campo (Lycalopex vetulus), cachorro-do-mato (Cerdocyon thous), anta (Tapirus terrestris), capivara (Hydrochaeris hydrochaeris), macaco-prego (Cebus apella) etc.

\footnotetext{
${ }^{4}$ Nomenclatura dos mamíferos atualizada conforme Fonseca et al. (1996).
} 
AVES: emas (Rhea americana), seriema (Cariama cristata), curicaca (Theristicus caudatus), perdiz (Rhynchotus rufescens), codorna (Nothura maculosa), arara-canindé (Ara ararauna), maracanã (Ara nobilis), papagaio-galego (Amazona xanthops), papagaio-verdadeiro (Amazona aestiva), pica-pau-do-campo (Coloptes campestris), pica-pau-branco (Melanerpes candidus), coruja-buraqueira (Athene cunicularia), suindara (Tyto alba), curiango (Nyctidromus albicollis), urutau (Nyctibius griseus), gavião-de-coleira (Falco femoralis), quiri-quiri (Falco sparverius), gaviãocarrapateiro (Milvago chimachima), gavião-do-rabo-branco (Buteo albicaudatus) carcará (Polyborus plancus), gavião-do-mangue (Circus buffoni), urubu-comum (Coragyps atratus), urubu-de-cabeça-vermelha (Cathartes aura), urubu-rei (Sarcoramphus papa), jacutinga (Pipile jacutinga), jacuguaçu (Penelope obscura), mutum (Crax fasciolata), Alma-de-gato (Piaya cayana), anu-preto (Crotophaga ani), quero-quero (Vanellus chilensis), asa-branca (Columba picazuro), pomba (Columba plumbea), fogo-apagou (Scardadella squammata), rolinha-asa-de-canela (Columbina minuta), rolinha-caldo-defeijão (Columbina talpacoti), várias espécies de passeriformes como pássaro-preto (Gnorimopsar chopi), gralha-do-campo (Cyanocorax cristatellus), galito (Alectrurus tricolor), sanhaço (Thraupis sayaca), tico-tico-do-campo (Coryphospiza melanotis), sabiá-do-campo (Mimus saturnius), sabiá-laranjeira (Turdus rufiventris), joão-de-barro (Furnarius rufus), tiziu (Volatinia jacarina), bem-te-vi-do-gado (Machetornis rixosus) etc.

RÉPTEIS: grande variedade de espécies de serpentes e lagartos, como o teiú (Tupinanbis teguixim).

Quanto a insetos, os que mais se destacam no ambiente são os cupins, que dão uma característica peculiar ao Parque, criando enormes cupinzeiros que se espalham em grandes quantidades por toda a unidade, fornecendo abrigo para tatus, corujasburaqueiras, pica-paus, papagaios, periquitos etc. (IBDF/FBCN, 1981; Redford, 1983 e 1987). 
$\mathrm{Na}$ estação chuvosa observa-se o fenômeno da bioluminiscência nos cupinzeiros, provocada pela larva de vaga-lume do gênero Pyrearinus, para atração de cupins alados para alimentação.

\subsubsection{Veado-campeiro (Ozotoceros bezoarticus)}

O veado-campeiro, Ozotoceros bezoarticus L. 1758 (Figura 4), é um dos sete cervídeos que há no Brasil. Pertence à ordem Artiodactyla, família Cervidae, sendo reconhecidas três subespécies: O.b.bezoarticus, que habita o centro-oeste brasileiro, sul da bacia Amazônica, margens do rio São Francisco, Rio Grande do Sul e Uruguai; O.b.leucogaster, que vive no sudoeste do Brasil, no sul do estado do Mato Grosso, Argentina e Paraguai; e $O$. b. celer, que ocorre nas regiões dos pampas, na Argentina, Paraguai e Bolívia (Carvalho, 1977; Redford, 1982 e Deutsch \& Puglia,1988).

Os machos possuem cerca de $1,20 \mathrm{~m}$ a $1,50 \mathrm{~m}$ de comprimento, $70 \mathrm{~cm}$ a $75 \mathrm{~cm}$ de altura e $30 \mathrm{~kg}$ a $40 \mathrm{~kg}$, sendo as fềmeas um pouco menores (Figura $4 \mathrm{a}$ ). Apenas os machos possuem galhadas de até três pontas, que medem cerca de $30 \mathrm{~cm}$ (Fonseca et al.,1994 e Jackson,1987).

Aos seis meses possuem chifres desenvolvidos, com uma ponta, que caem no ano seguinte, sendo logo substituídos, por chifres com 2 pontas. Ao atingirem a idade de três anos, os chifres desenvolvem 3 pontas e não se acrescentará mais pontas as galhadas, ao longo dos anos, apenas o comprimento continuará a se desenvolver.

A coloração de seu pêlo é castanho-clara, com manchas em várias partes do corpo. Seus olhos se destacam por possuírem um contorno branco, sendo apelidado em muitas regiões de "veado-de-óculos". São brancas também as faces internas das orelhas, do pescoço, dos membros, da cauda, do perineo e do abdome (Deutsch \& Puglia, 1988).

São animais de maior ocorrência em áreas abertas, sendo raramente observados em áreas fechadas.

A alimentação predileta dos veados são flores e folhas, principalmente tenras, e quando não há oferta dos mesmos, alimentam-se de gramíneas e ervas. Mas pela necessidade de suprir a falta de sal (Rodrigues, 1996), bem como pela oferta nutritiva 

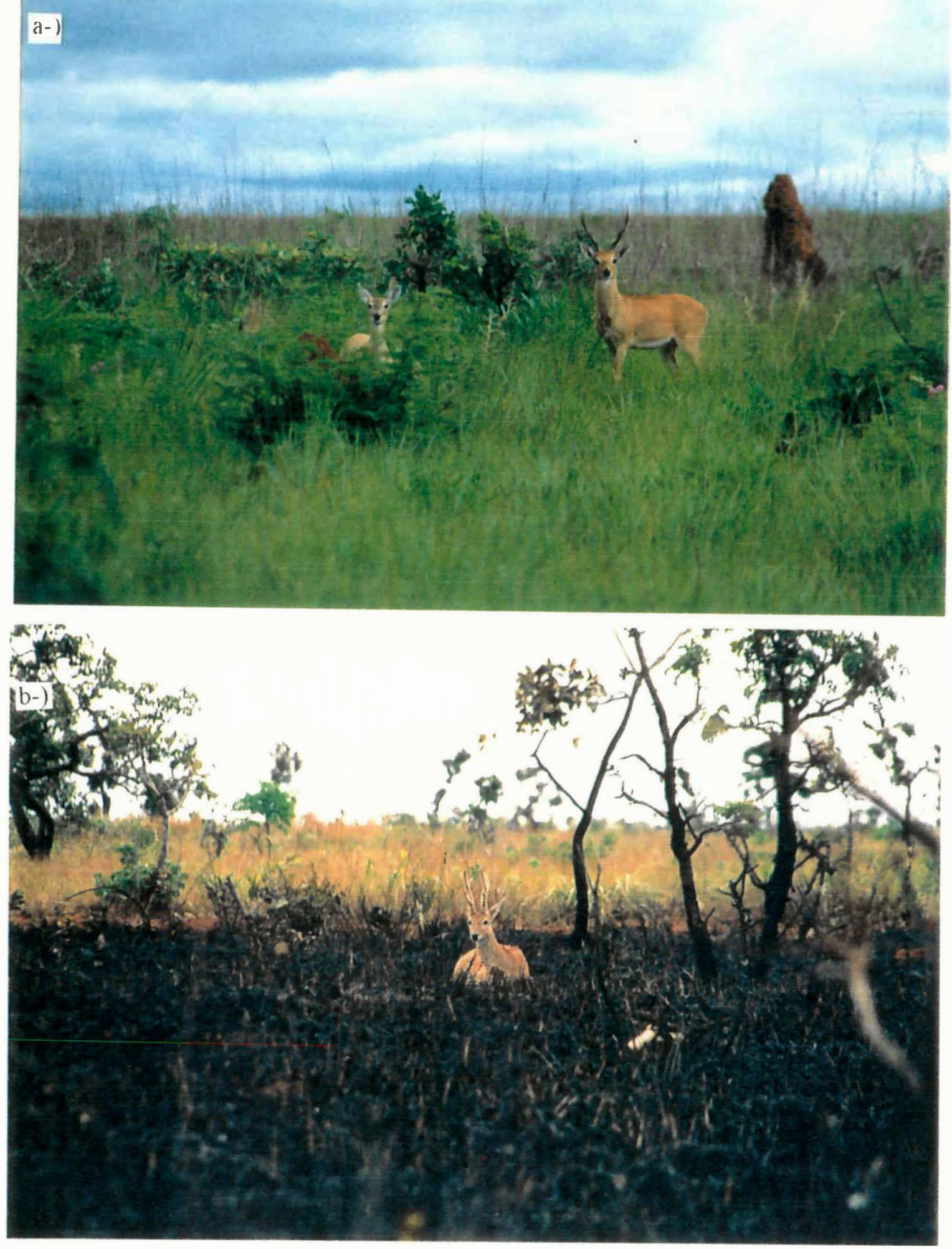

Figura 4 - Veado-campeiro (Ozoloceros bezoctrlicus): a-) Fêmea e macho em aceiro regenerado e b-) Macho em aceiro recém-queimado. 
encontrada nas cinzas (Coutinho, 1990b), são freqüentemente visualizados lambendo cinzas em aceiros recém-queimados.

O fogo, por observações realizadas no Parque por pesquisadores do Projeto Cervídeos, IBDF/FBCN (1981) e Rodrigues (1996), é um dos principais agentes do deslocamento do veado-campeiro, que o atrai para as regiões queimadas (Figura $4 b$ ), onde se alimentam das cinzas, que é um complemento alimentar. Esta atração também ocorre com outras espécies de cervídeo, como o norte-americano veado-de-cauda-preta (Odocoileus hemionus) (Keay \& Peek 1980) que, como o veado-campeiro, ocorrem em áreas abertas.

Sua maturidade sexual ocorre em torno de 1 ano de idade. A corte ocorre no . verão e sua gestação é de 210 dias (Deutsch \& Puglia, 1988 e Fonseca et al., 1994), nascendo geralmente um filhote, podendo ocorrer casos raros de gêmeos. Os filhotes nascem entre o final da estação seca e início da estação chuvosa, setembro e outubro (Rodrigues, 1996), sofrendo algumas variações em outros países.

As fềmeas, na hora de gerar os filhotes, afastam-se da presença de outros indivíduos e das regiões baixas, para se isolarem em regiões altas do Parque, onde procriam. Permanecem com os filhotes por oito meses, ensinando-os a se alimentarem e a se protegerem (Silva, $C^{5}$. 1997).

Um aspecto importante no entendimento do ciclo reprodutivo dos cervídeos é o acompanhamento do crescimento anual dos chifres, que ocorrem sob influência hormonal, principalmente pela testosterona. Os chifres dos veados caem e voltam a crescer anualmente e, durante o seu crescimento, permanecem envoltos por uma pele denominada velame, que cai quando se dá o desenvolvimento completo dos mesmos, deixando o tecido ósseo exposto (Rodrigues, 1996).

Concluída a época de reprodução, o nível de testosterona no sangue baixa, os chifres caem e as glândulas odoríficas, reduzem a produção de odores. Estas glândulas se situam nas regiões infra-orbitais, traseira e interdigital (Jackson, 1987), e seus excretas são utilizados para marcar território e atrair as fềmeas, pelo forte ardor exalado.

\footnotetext{
${ }_{5}^{5}$ Silva,C.M. (Auxiliar Técnica do Projeto Cervídeos do Brasil) Comunicação pessoal.
} 
Os animais podem viver isolados ou em grupos não fixos, como observado por Tomás (1988), Fonseca et al. (1994) e Rodrigues (1996). Os grupos variam quanto à quantidade de indivíduos, podendo ser de dois a quinze indivíduos. Estes agrupamentos de grande quantidade de animais, ocorrem principalmente em locais onde há uma grande oferta alimentar e, quando esta regiões se esgotam, os animais se espalham novamente. No entanto, o mais comum e viverem isolados ou em grupos pequenos de dois a três indivíduos, no máximo.

Os deslocamentos diários são realizados no período diurno e noturno e foram calculados em média de $1,64 \pm 0,52 \mathrm{Km}$, considerados grandes em relação a outros cervídeos (Rodrigues, 1996). Em outras regiões, como no Distrito Federal, a área de vida foi estimada em $5,9 \mathrm{Km}^{2}$ e deslocamento de $2 \mathrm{Km}$. Mas estes dados podem estar relacionados à oferta de alimento, habitat e água.

Cada veado pode sobrepor no mínimo $80 \%$ de sua área de vida com a de outros indivíduos, facilitando a divisão dos recursos disponíveis no Parque, como água, alimentos, etc. Isto favorece grandemente a sobrevivência da espécie (Rodrigues, 1996).

São muito tolerantes ao conviveu com outras espécies, principalmente Emas (Rhea americana), sendo encontrados juntos, geralmente em áreas com grande oferta alimentar, como defesa contra predadores.

Os seus predadores naturais são a suçuarana ou onça-parda (Puma concolor), onça-pintada (Panthera onca) e lobo-guará (Chrysocyon brachyurus), que por constatações no Parque, ataca apenas os filhotes, não havendo relatos de ataques a adultos. Estes confrontos são de rara ocorrência, pois a principal alimentação dos lobos é constituída de frutas, pequenos roedores e aves como as codornas (Nothura maculosa) e perdizes (Rhynchotus rufescens) (Fonseca et al.,1994).

$\mathrm{Na}$ realidade, o maior perigo que a espécie encontra é a caça e a perda de seu habitat para o gado e a agricultura (Carvalho,1977; Cravino,1988; Jackson \& Langguth, 1982 e Fonseca et al.,1994). 


\subsubsection{Mapas e equipamentos}

Para a realização deste trabalho, foram utilizados os seguintes mapas e equipamentos:

- Carta planialtimétrica do Parque, IBDF/FBCN, escala 1:50.000, de 1978;

- Imagens de satélite cedidas pelo INPE: cena WRS 224/073N+ (29/07/88), cena WRS $224 / 073 \mathrm{~N}+(18 / 08 / 92)$ e WRS 224/072D + (25/08/95), do sensor TM do Landsat-5, nas bandas 3(R), 4(G) e 5(B), na escala 1:100.000;

- Tosca: software para digitalização e edição de dados vetoriais;

- Idrisi for Windows v.2.0: software de Sistema de Informações Geográficas;

- Surfer 5.0: software para modelagem digital de terrenos;

- Microcomputador PC 486/DX4;

- Mesa digitalizadora Summagraphics Microgrid III, A0;

- Impressora a jato de tinta: Hewlett Packard - Deskjet 660 C;

- Receptor GPS portátil, Eagle Accunave;

- Medidor óptico de distância ("rangefinder"): Rangematic -1000;

- Binóculo: Selsi $8 \times 21$;

- Câmera fotográfica: Nikon F50;

- Automóvel para deslocamento no Parque: Volkswagen Sedan, 1977, gentilmente emprestado pelo projeto Cervídeos do Brasil;

- Avião monomotor para sobrevôo de checagem: Taylor Craft (PP-DRN);

- Gravador portátil : Panasonic RN-302

\subsection{Métodos}

Para atingir os objetivos deste trabalho, seguiu-se a metodologia indicada para trabalhos que se utilizam do SIG em estudos de distribuição de fauna, com adaptações específicas para se atingir a solução final. 


\subsubsection{Levantamento bibliográfico e cartográfico das variáveis importantes ao estudo}

a-) Animal: dados biológicos e comportamentais.

Utilizou-se de todas as informações possíveis sobre o animal, adquiridas por levantamento bibliográfico, para se ter uma compreensão adequada sobre a espécie.

Este procedimento é de grande importância, para que se possa ter uma análise de como o animal se adapta e toma decisões, na escolha dos melhores locais para sua sobrevivência.

b-) Ambiente: $O$ Parque e a relação do animal com o ambiente.

Foram coletadas informações das características da área de estudo, como localização, clima, vegetação, limites, relevo, estradas internas e externas, impacto humano, habitações dentro do Parque e próximas a ele, fauna local, uso da terra no entorno do Parque etc.

Em estudos como este é importante buscar na bibliografia informações da relação do animal com ambiente e formar um banco de dados com informações de distribuição da espécie. Neste caso é essencial que já haja um bom banco de dados sobre a espécie na região e mesmo sobre o local onde será realizado o projeto, para que haja a redução do tempo e do custo do mesmo.

Caso não haja um banco disponível é necessário gerá-lo, aumentando o custo e tempo de execução do projeto.

Neste projeto, o banco de dados utilizado foi o da UNESP-Jaboticabal, que desenvolveu o projeto Cervídeos do Brasil no Parque Nacional das Emas e no Pantanal, com o veado-campeiro, abrangendo estudos biológicos gerais da espécie:

\subsubsection{Trabalho de campo}

Visitou-se a unidade de conservação para se obter um maior contato com a área, reconhecendo os ambientes e características particulares da mesma, e o 
comportamento e localização do veado-campeiro no local, com a finalidade de desenvolver um senso crítico coerente, no momento de analisar os resultados finais.

Nestas visitas também foram analisados o banco de dados da UNESPJaboticabal e informações locais fornecidas pela assistente técnica do Projeto Cervídeos e outros.

a-) Ambiente:

Estudou-se o ambiente do parque quanto à vegetação, oferta alimentar, hidrologia, dinâmica do fogo, impacto humano, clima, relevo, estradas internas e externas e uso da terra no entorno do parque.

b-) Distribuição do animal no Parque e sua relação com o mesmo:

Analisou-se as informações das freqüências do animal nos ambientes do Parque, alimento, o efeito do fogo sobre o animal, a importância da água, o efeito de seleção de um habitat, comportamento, o impacto humano sobre a espécie dentro e fora do Parque (próximo aos limites do Parque) ocasionando o efeito de atração do animal pelas áreas agrícolas e pecuárias ao redor do Parque, as estradas dentro e fora do Parque e edificações dentro da unidade de conservação.

\subsubsection{Produção do mapa de probabilidade de ocorrência, por meio de um SIG}

\subsubsection{Abordagem empregada}

Na elaboração do mapa de probabilidade de ocorrência do veado-campeiro no PNE, foi empregada a abordagem "multi-critérios/único objetivo", para a tomada de decisões em ambiente SIG, conforme Eastman et al. (1993). 


\subsubsection{Definição dos fatores e restrições}

No processo de tomada de decisão, a base para uma decisão, que pode ser medida e avaliada, é chamada de critério. Os fatores são critérios que realçam ou diminuem a adequação de uma aitternativa específica para a atividade sob consideração.

Assim, na definição dos fatores importantes ao Projeto, bem como dos seus pesos relativos, utilizou-se a chamada técnica participatória, também conforme Eastman et al. (1993).

Em reunião realizada no próprio Parque, em março de 1997, envolvendo a bióloga executora do projeto, o seu orientador e a guia do Parque (contratada temporariamente pelo Projeto), definiu-se quais poderiam ser os possíveis fatores principais, que influenciariam diretamente na distribuição do cervídeo no Parque, que seriam posteriormente testados, no decorrer do emprego da metodologia em uso.

\subsubsection{Digitalização dos planos de informação}

Para a digitalização dos planos de informação necessários ao trabalho, utilizouse o software Tosca e uma mesa digitalizadora A0 ligada a um microcomputador 486 .

O sistema de coordenadas utilizado foi o UTM (Universal Transverso de Mercator), unidades em $\mathrm{Km}$, com as seguintes coordenadas para mapeamento: mínimo de $\mathrm{x}=274 \mathrm{Km}$; máximo de $\mathrm{x}=318 \mathrm{Km}$; mínimo de $\mathrm{y}=7968 \mathrm{Km}$ e máximo de $\mathrm{y}=$ $8026 \mathrm{Km}$.

Foram digitalizadas da carta planialtimétrica, algumas das principais informações para o estudo: os rios, limites do Parque, as estradas internas, os aceiros, as áreas úmidas, os campo, as matas, as estradas, a topografia e as duas rodovias fora do Parque. 


\subsubsection{Cálculo dos pesos dos planos}

Analisadas todas as informações adquiridas e os principais planos de informação que afetam diretamente a distribuição do animal no Parque, procedeu-se à geração dos pesos para cada plano. Foi adotado o procedimento de Eastman et al.(1993 e 1995), para a utilização em ambiente SIG. Este procedimento baseia-se na elaboração de uma matriz de comparações entre os planos (que representam os fatores de estudo), de acordo com a importância relativa entre pares de planos adotados.

Os valores atribuídos aos planos são derivados de uma escala contínua de 9 pontos, sendo que os planos são comparados entre si, dois a dois, e classificados segundo a importância entre eles, variando desde extremamente menos importante até extremamente mais importante (valores $1 / 9$ e 9 , respectivamente, conforme Tabela 1). A partir dessa escala construiu-se a matriz de comparação entre fatores, usada no cálculo de seus respectivos pesos, por meio da função WEIGHT, do Idrisi.

Para o resultado final dos pesos gerados é apresentado um valor, chamado de Taxa de Consistência (TC), que deve estar abaixo de 0,10 para que os pesos obtidos possam ser considerados consistentes.

Finalizada esta meta, os valores foram posteriormente arquivados pelo módulo comando EDIT, em forma de arquivo de comparação pareada.

Tabela 1 - Escala utilizada na geração da matriz de comparação entre planos (Eastman et al.,1993).

\begin{tabular}{|c|c|c|c|c|c|c|c|c|}
\hline $\begin{array}{c}\text { Extrema- } \\
\text { mente }\end{array}$ & $1 / 9$ & $1 / 5$ & $1 / 3$ & 1 & 3 & 5 & 7 & 9 \\
$\longleftrightarrow$ & Muito & $\begin{array}{c}\text { Forte- } \\
\text { Mente }\end{array}$ & $\begin{array}{c}\text { Modera- } \\
\text { damente }\end{array}$ & $\begin{array}{c}\text { Igual- } \\
\text { mente }\end{array}$ & $\begin{array}{c}\text { Modera- } \\
\text { damente }\end{array}$ & $\begin{array}{c}\text { Forte- } \\
\text { Mente }\end{array}$ & $\begin{array}{c}\text { Muito } \\
\text { mextrema- } \\
\text { mente }\end{array}$ \\
\hline
\end{tabular}




\subsubsection{Geração do mapa de probabilidade de ocorrência}

O mapa de probabilidade de ocorrência foi gerado pela função MCE (MULTICRITERIA EVALUATION) do Idrisi, que executa a operação de combinação linear ponderada entre os planos relativos aos fatores. Por fim, esse último mapa foi reclassificado de modo a apresentar 3 faixas de probabilidade de ocorrência, de mesma amplitude de valores, ou seja: regiões de maior, média e menor probabilidades.

\subsubsection{Amostragem por meio de levantamento aéreo}

Para se ter a confirmação da eficiência do mapa gerado pelo SIG, realizou-se uma amostragem por meio de um levantamento aéreo na área de estudo. Este sobrevôo foi realizado apenas com um observador (o pesquisador), num avião Taylor Craft (PPDRN), voando a altura de $60 \mathrm{~m}$ acima do solo, a velocidade de $150 \mathrm{Km} / \mathrm{h}$.

Para demarcação da área amostrada, visualizou-se uma faixa de $200 \mathrm{~m}$ paralela ao lado direito do avião, que era delimitada pela vareta da asa da aeronave (Figura 5). A cada observação da espécie, nesta faixa, eram registrados por voz, em um gravador portátil, a posição georeferenciada (por meio de um receptor GPS), o ambiente, o sexo, a quantidade e o horário.

Estas contagens foram realizadas por varredura visual entre 30/07/97 a 04/08/97, portanto na estação seca, no começo da manhã e no final da tarde, por ocorrer menos vento e ser o horário de pico de movimentação do veado-campeiro (observações locais).

Totalizaram-se 10 horas de vôo e $809 \mathrm{Km}$ de linha contínua de percurso, que foi dividida em 28 transectos, sistematicamente amostrados, sendo 26 dentro dos limites do Parque e 2 fora dos limites. Os transectos tinham direção leste-oeste, separados pela distância de $2 \mathrm{Km}$, com comprimentos variáveis. 


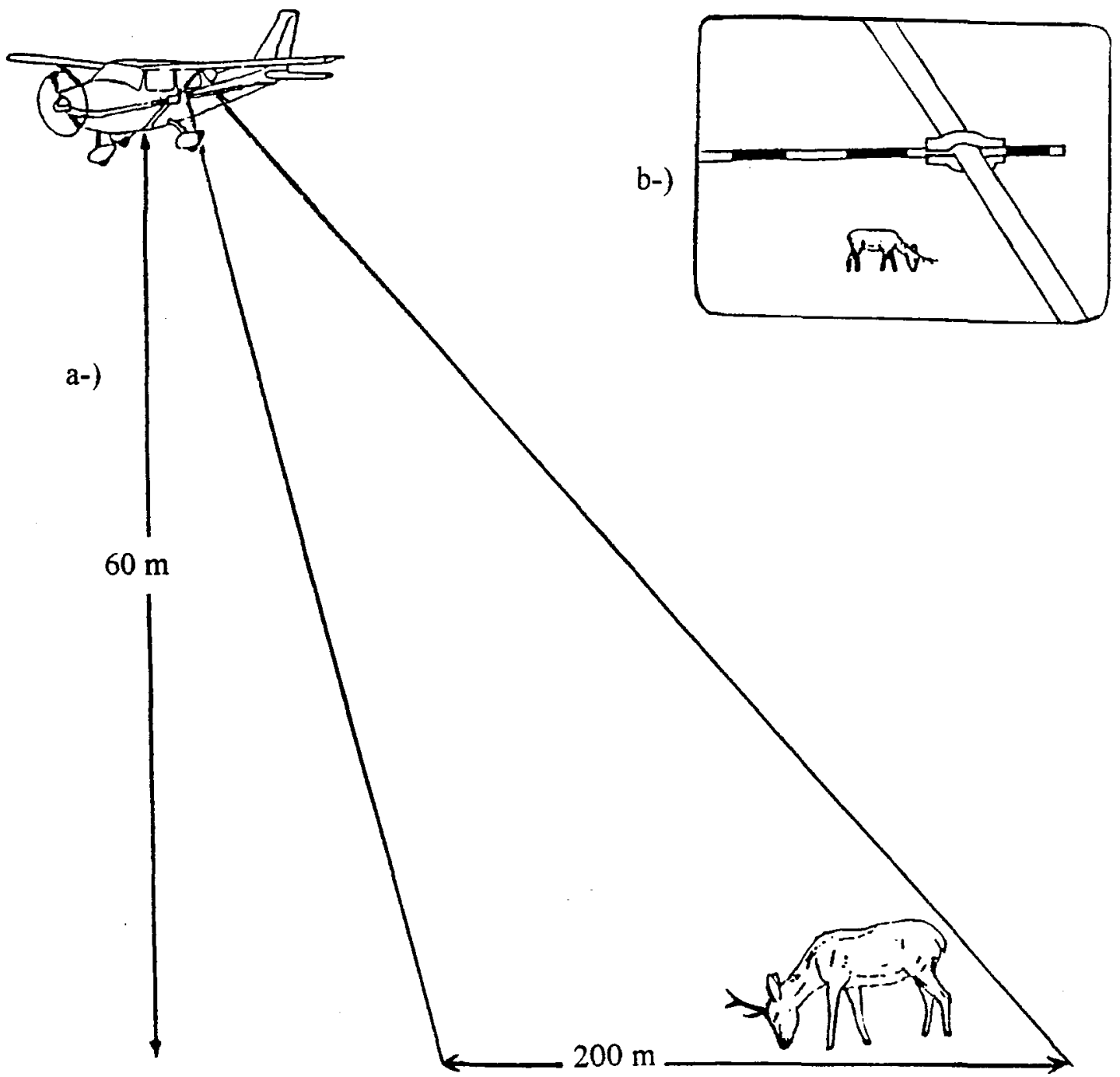

Figura 5 - a-) Visão sistemática do método de amostragem usado para o levantamento do Veado-campeiro (Ozotoceros bezoarticus) no Parque Nacional das Emas; b-) Visão do observador, com a vareta delimitando a área amostrada (Mauro, 1993). 
Do lado leste estabeleceram-se mais 14 transectos e do lado oeste do Parque mais 13 transectos, todos em formato de $\mathrm{U}$.

Os transectos criados fora dos limites do Parque foram gerados para se poder obter maiores informações sobre o seu entorno.

Totalizando apenas os transectos percorridos dentro dos limites do Parque, obteve-se $640 \mathrm{~km}$ de linhas amostradas.

Estes transectos foram todos georeferenciados, em suas devidas coordenadas UTM e gravados no GPS de bordo, para que o piloto pudesse se guiar e não se perder, da rota dos transectos, sobre o Parque.

\subsubsection{Amostragem terrestre}

De acordo com orientação estatística, foi realizado um novo trabalho de campo, para confirmação dos dados obtidos com o sobrevôo.

Nesta checagem foi utilizada nova metodologia para determinação dos locais de ocorrência do veado-campeiro, que consistiu em percorrer de carro, 30 faixas de $6 \mathrm{Km}$ de comprimento, anotando-se apenas os animais observados a $50 \mathrm{~m}$ de cada lado da estrada.

Para se atenuar o erro na avaliação da distância animal-observador, foi utilizado um distanciômetro óptico portátil (Rangematic 1000).

A cada observação eram anotados: posição (georeferenciada por GPS), a quantidade de animais, sexo e ambiente.

Esta amostragem foi realizada entre os dias 15/11/97 a 19/11/97, durante o dia.

\subsubsection{Análise estatística}

Com o mapa final de distribuição devidamente classificado em 3 (três) faixas de probabilidade de ocorrência do veado-campeiro, realizou-se o cruzamento deste produto com os dados obtidos pelo sobrevôo e pela checagem terrestre. 
Desta sobreposição, efetuou-se a análise de variância no campo não-paramétrico para ambos os resultados, para o estudo da quantidades de animais visualizados, sobre o plano final gerado no SIG. O teste utilizado foi o de Kruskal-Wallis, um substituto do teste $\mathrm{F}$ do campo paramétrico (Campos, 1979) que, ao se admitir $k$ tratamentos, permite averiguar se há diferença entre pelo menos dois deles, ou seja, testar as seguintes hipóteses:

$\mathrm{H}_{0}: \mathrm{t}_{1}=\mathrm{t}_{2}=\ldots=\mathrm{t}_{\mathrm{k}} ;$

$\mathrm{H}_{\mathrm{a}}$ : pelo menos dois tratamentos diferem entre si.

Suas pressuposições são:

a-) As observações são todas independentes;

b-) Dentro de uma dada amostra, todas as observações são provenientes da mesma população;

c-) As $k$ populações são aproximadamente da mesma forma e contínuas.

Definição estatística:

$$
H=\frac{12}{N(N+1)} \sum_{i=1}^{k} \frac{R_{i}^{2}}{n_{1}}-3(N+1)
$$

Cumpre observar que:

a-) Para $k=2$, empregamos o teste bilateral de Wilcoxon;

b-) À medida que o $n_{i}$ cresce, a distribuição nula de $H$ tende à distribuição de ${ }_{X}^{2}$, com $(k-I)$ graus de liberdade. Portanto, para $n_{i}>6$ aplica-se a aproximação do ${ }_{X}^{2}$;

c-) Para $\mathrm{k}>3$, aplica-se também a aproximação do $x_{x}^{2}$, com $(k-l)$ graus de liberdade, isto é, consulta-se o nível de significância, para o valor de $H$ calculado, numa tabela comum $\operatorname{de}_{X}^{2}$ (Campos, 1979 e Zar, 1984).

Como o teste de Kruskal-Wallis admite diferenças entre os tratamentos, não 
indicando aonde ela ocorre, utilizou-se o mesmo teste para comparar os tratamentos entre si, para localizar as diferenças significativas entre os pares de tratamentos. Para tanto, foi utilizado o software SAS.

Quanto à estimativa populacional para o Parque, os cálculos utilizados foram baseados em Caughley (1980) e Mourão \& Magnusson (1997) e apresentados a seguir:

As fórmulas para densidade e número estimado, respectivamente:

$D=\sum y / \sum a \quad$ e $\quad Y=A * D$

E para o erro-padrão, nos casos onde não há reposição:

$S E(D)=n / \sum a * \sqrt{\left[1 / n(n-1) *\left(\sum y^{2}+D^{2} \sum a^{2}-2 D \sum a y\right)\right]} * \sqrt{\left[1-\left(\sum a\right) / A\right]}$

$\operatorname{SE}(Y)=A * \operatorname{SE}(D)$

Notação:

$y=$ número de animais em uma dada unidade amostral;

$a \quad=$ área de uma dada unidade amostral;

$A \quad=$ área total da região do levantamento;

$n \quad=$ número de unidades amostradas;

D ou $d$ = densidade média estimada;

$S E(D)$ = erro-padrão da densidade média estimada;

$Y \quad=$ número total estimado para regiões de tamanho A;

$S E(Y)$ = erro-padrão do número total estimado. 


\section{RESULTADOS E DISCUSSÃo}

\subsection{Geração dos planos de informação}

Foram gerados 15 planos de informação, que são apresentados a seguir com seus respectivos identificadores (Tabela 2):

Tabela 2 - Planos de informação gerados.

\begin{tabular}{|c|c|c|}
\hline Número & $\begin{array}{c}\text { Planos de } \\
\text { Informacões }\end{array}$ & $\begin{array}{c}\text { Nome Identificador dos } \\
\text { Planos de Informacões }\end{array}$ \\
\hline $\mathbf{1}$ & Aceiro & Aceiro \\
\hline $\mathbf{2}$ & Campo & Campo \\
\hline $\mathbf{3}$ & Mata & Mata \\
\hline $\mathbf{4}$ & Campos úmidos & Umi \\
\hline $\mathbf{5}$ & Hidrografia & Hidro \\
\hline $\mathbf{6}$ & Rios & Rios \\
\hline $\mathbf{7}$ & Topografia & Top \\
\hline $\mathbf{8}$ & Estradas internas & Estradas \\
\hline $\mathbf{9}$ & Rodovia asfaltada & Rodasf \\
\hline $\mathbf{1 0}$ & Rodovia de terra & Rodter \\
\hline $\mathbf{1 1}$ & Alojamentos & Aloj \\
\hline $\mathbf{1 2}$ & Sede de Fazendas & Faz \\
\hline $\mathbf{1 3}$ & Pecuária & Pecua \\
\hline $\mathbf{1 4}$ & Área Agrícola & Agric \\
\hline $\mathbf{1 5}$ & Área do Parque & Parque \\
\hline
\end{tabular}

O plano de informação digitalizado da carta planialtimétrica, referente à vegetação, originou os dois principais planos para ambientes: a-) Campo: onde se 
incluem o campo limpo, campo sujo e o campo cerrado e b-) Mata: incluindo a mata ciliar, as veredas e mata mesofitica de interflúvio.

O plano de hidrografia foi gerado pela soma dos planos de campos úmidos, que representam regiões permanentemente úmidas e com tendência à inundação (onde estão representados também os campos de murunduns) e o plano de informação de rios.

As áreas agrícola e pecuária, foram mapeadas apenas na faixa de $1 \mathrm{~km}$ ao redor do Parque, de acordo com a bibliografia, que estima em média esta distância de afastamento do Parque pelos animais (Rodrigues, 1996) e informações locais.

Os demais planos de informação e variáveis de estudo, foram gerados diretamente no SIG, utilizando-se dos pontos georeferenciados, como as sedes de fazendas próximas à unidade de conservação, áreas de uso de solo diferenciando a pecuária da agricultura, construções dentro do Parque e locais de visualização, tanto terrestres como aéreos.

Estes planos foram gerados de informações obtidas por meio de visitas ao Parque e pela análise de imagens de satélite, de datas as mais recentes possíveis e disponíveis.

\subsection{Geração do mapa de probabilidade de ocorrência}

\subsubsection{Seleção dos planos de maior importância ao estudo}

Pela técnica participatória e pela análise dos planos de informação, que representam os fatores do estudo, verificou-se a importância de três planos de maior impacto sobre a distribuição da espécie no Parque, em época seca, que eram o aceiro, a hidrologia e sedes de fazendas.

Classificados em grau de importância, o principal fator de atração eram os aceiros, seguido do hidrológico. As sedes das fazendas foram considerados como fator de repulsa para o veado-campeiro. 
$1^{\mathbf{0}}$ ) Aceiros (Figura 6): $\mathrm{O}$ fogo participa naturalmente dos cerrados, atuando diretamente em seus ambientes, diminuindo a fitomassa e provocando sua renovação. Os aceiros apenas exercem o papel induzido de uma queimada natural, com estágios de atração da fauna.

Depois que ocorre a queimada, o principal fator de atração são as cinzas que ficam no local, depois será a rebrota da vegetação, florescimento e germinação das sementes de espécies vegetativas e no último momento o surgimento de frutos.

Estes locais, tornam-se ideais para a permanência do cervídeo, dentre outros animais encontrados no Parque, até o encerramento da oferta alimentar, provocando novo deslocamento do animal na região, até encontrar outros locais onde possam ter ocorrido queimadas ou haja alimentação adequada.

Os aceiros são utilizados também como corredores de movimentação da fauna local, juntamente com as estradas que seguem paralelamente a eles. Outro fator importante, é que estes locais oferecem aos cervídeos a condição fisica ideal, por serem campos totalmente abertos, facilitando a visualização e fuga de predadores.

$2^{\mathbf{0}}$ ) Hidrografia (Figura 7): Os rios estão quase sempre são margeados por mata ciliar ou veredas, assim os veado quase sempre obtém água através de fontes ou bolsões nas áreas úmidas, ou nos próprios rios, quando as margens são rasas e a mata ciliar ou a vereda são menos densas.

A água é um dos principais fatores de sobrevivência dos seres vivos e no caso do cervídeo em estudo, dificilmente eles se afastam para áreas de difícil acesso à água, a não ser em deslocamentos para outras regiões do Parque.

Isto pode ocorrer, pela necessidade de obter alimento, procurando novos locais com boa oferta alimentar, ou fatores ligados ao comportamento: procriação, delimitação de territórios dos machos jovens etc. ${ }^{6}$

\footnotetext{
${ }^{6}$ Não foram estudados no Parque, os fatores principais que provocam o deslocamento do veado-campeiro.
} 


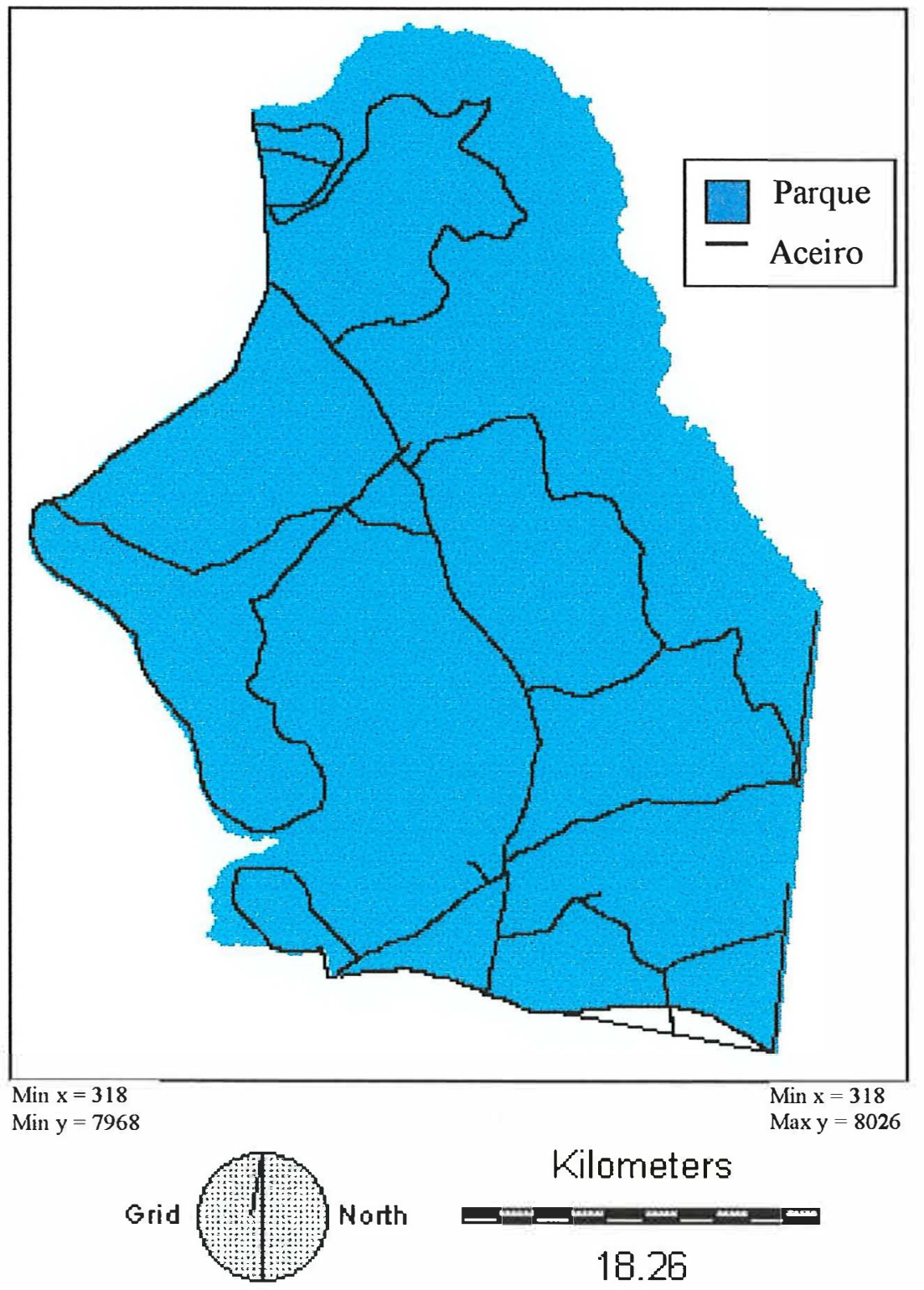

Figura 6 - Plano de informação "Aceiros". 


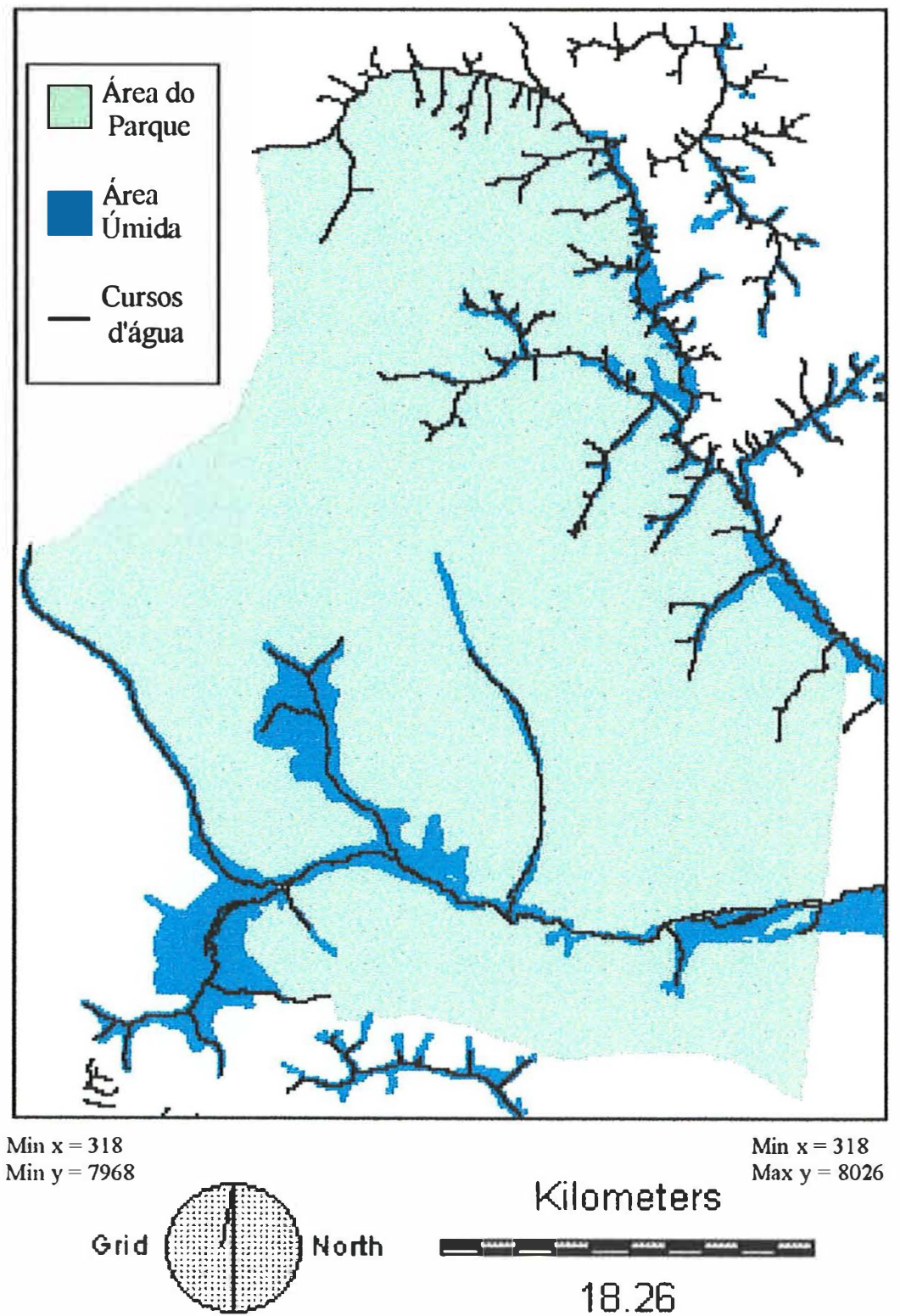

Figura 7 - Plano de informação "Hidrografia". 
$3^{\text {o }}$ ) Sedes de fazendas (Figura 8): Existem 51 sedes de fazendas no entorno do Parque, sendo que 25 estão situadas na faixa de $1 \mathrm{Km}$ ao redor ${ }^{7}$ dos limites do Parque e as demais ultrapassam esta faixa.

As sedes próximas ao Parque foram levadas em conta, para estudo de caso, demonstrando que realmente na presença humana intensiva, ocorrem fatores que provocam o afastamento dos animais silvestres, quando eventualmente saem do Parque e tentam se aproximar das sedes das fazendas. Estes fatores são movimentação de máquinas agrícolas, veículos, de pessoas, presença de animais domésticos e entorno impactado.

No caso das construções dentro do Parque, não ocorre a repulsa, pela falta de grandes movimentações (pessoas e veículos) e o entorno destes locais ser pouco impactado ${ }^{8}$. Outros fatores que impedem a ida dos animais a estas sedes são barreiras naturais, como os rios e vegetação alta (vereda, mata ciliar ou mata mesófila de interflúvio).

Ás estradas (não asfaltadas e as pavimentadas) não são obstáculos, pois foi constatada a presença de veados em plantações de soja em torno do Parque, sempre em épocas de colheita ou de plantio.

$\mathrm{Na}$ análise multi-critérios/único objetivo, dois planos de informação foram utilizados como restrição: "Campos" (Figura 9) e "Limite do Parque".

Campos (Figura 9): Representação dos ambientes de campo limpo, campo sujo e campo cerrado que são considerados os habitats naturais da espécie em estudo e com maior representatividade fisionômica do Parque, englobando quase toda a unidade, como poder ser notado na própria Figura 9. Assim, por estas características, este plano

\footnotetext{
${ }^{7}$ Faixa estipulada de deslocamento dos animais do Parque, para fora de seus limites, conforme bibliografia.

${ }^{8}$ Muitas vezes foram avistados veados a 100 metros das habitações, alimentado-se de vegetação local, bem como outros mamúferos.
} 
foi utilizado como uma máscara para restringir as áreas de provável ocorrência do cervídeo em áreas abertas.

Limites do Parque: Também foi aplicado como uma "restrição", obviamente para restringir as análises aos limites do Parque Nacional das Emas. 


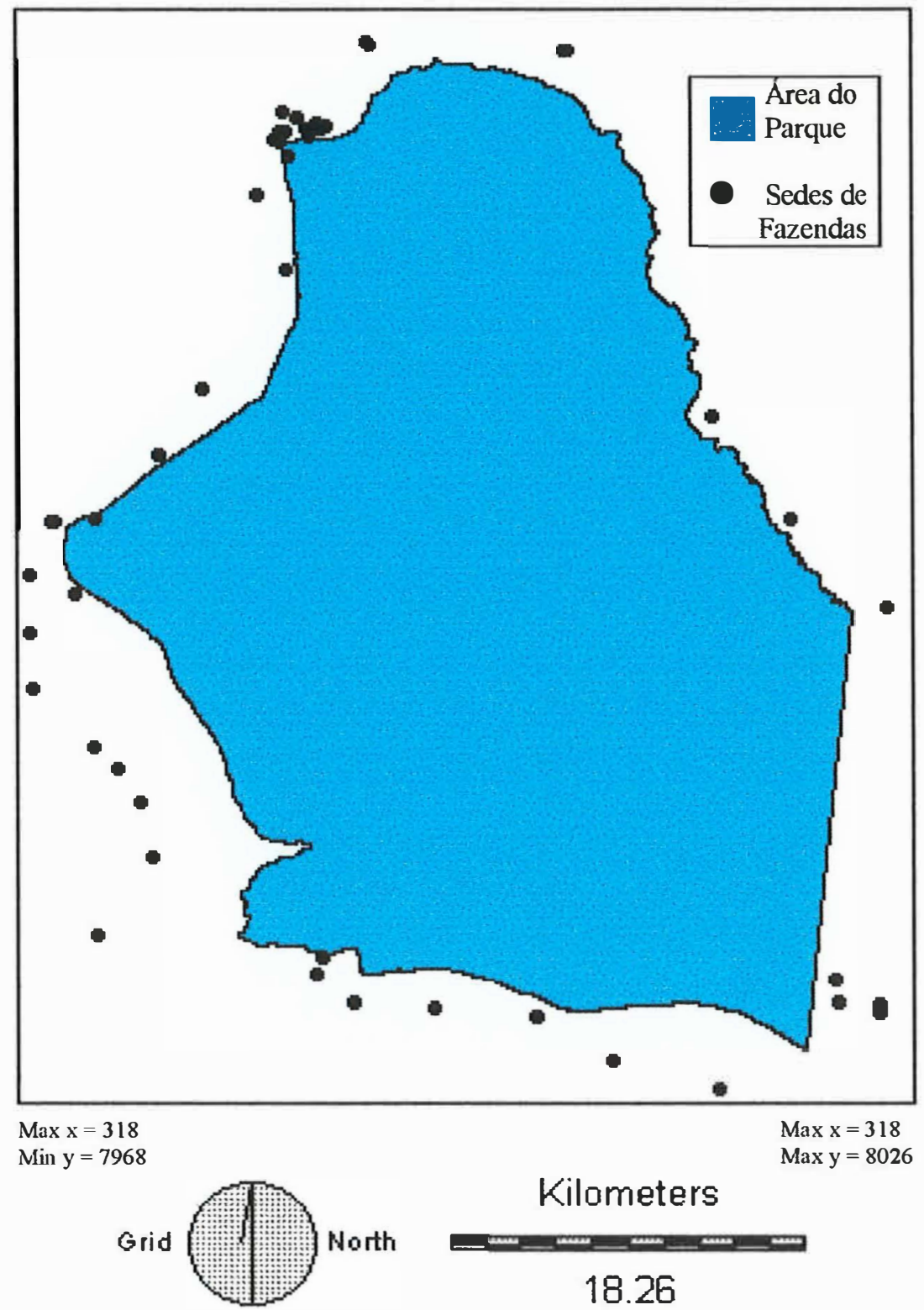

Figura 8 - Plano de informação "Sedes de Fazendas". 
Min $x=274$

$\operatorname{Min} x=274$

Min $y=7968$

Max $y=8026$

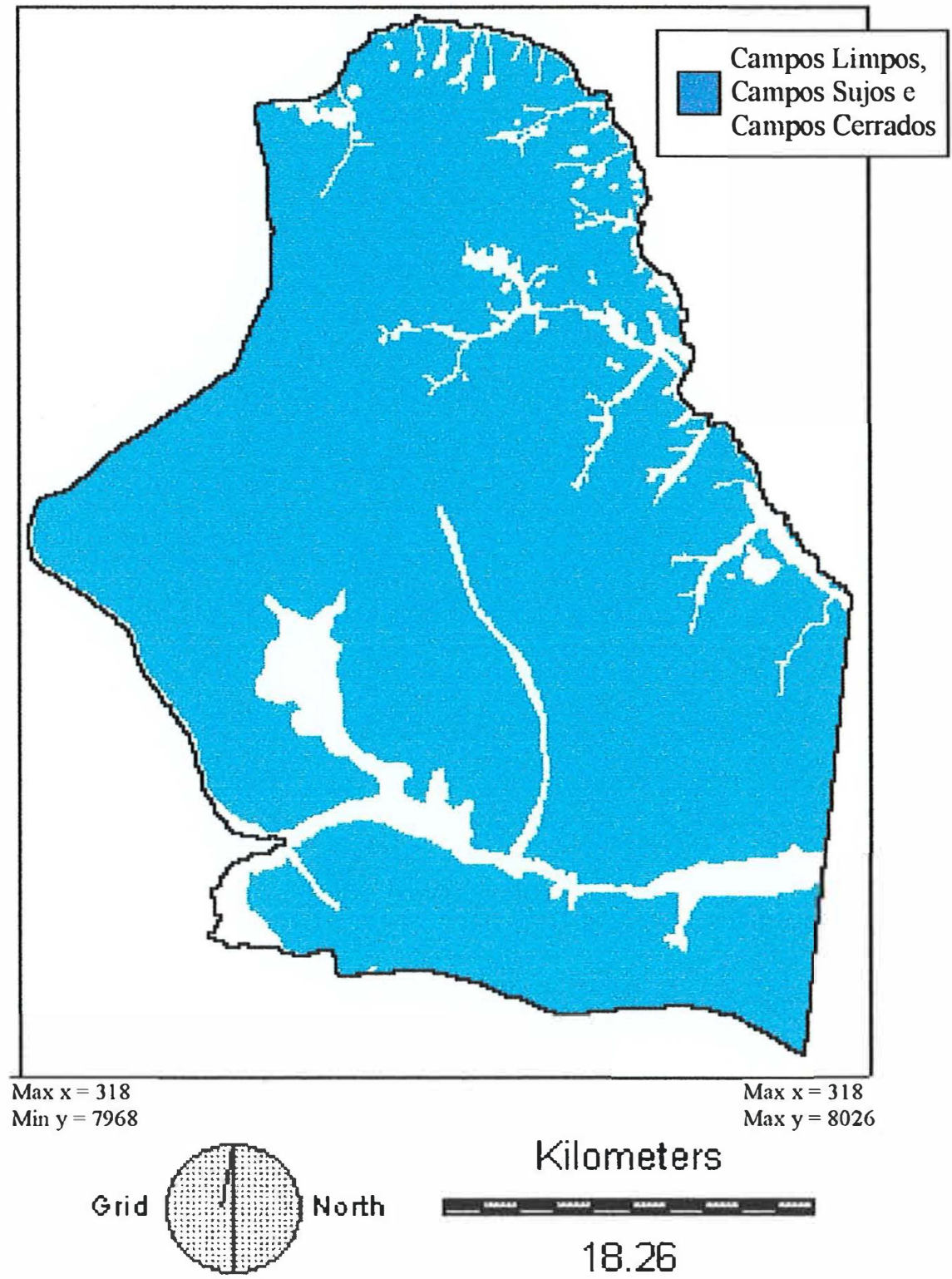

Figura 9 - Plano de Informação "Campos". 


\subsubsection{Ponderação dos planos}

Definidos os planos a serem empregados no trabalho, o passo seguinte foi a definição dos pesos para cada um deles.

Por meio da técnica participatória, os planos foram comparados dois a dois, quanto à sua importância relativa, estabelecendo-se valores para estes, conforme a Tabela 1. Desta comparação, originou-se a matriz de comparação pareada, apresentada na Tabela 3 .

Tabela 3 - Matriz de comparação pareada.

\begin{tabular}{|c|c|c|c|}
\hline Planos & Aceiro & Hidro & Faz \\
\hline Aceiro & 1 & & \\
\hline Hidro & $1 / 3$ & 1 & \\
\hline Faz & $1 / 6$ & $1 / 5$ & 1 \\
\hline
\end{tabular}

Por meio da função Weight, do Idrisi, e usando-se os valores acima, foram calculados os pesos dos fatores (Tabela 4).

Tabela 4 - Valor do peso de cada fator.

\begin{tabular}{|c|c|}
\hline Fator & Peso \\
\hline Aceiro & 0,6348 \\
\hline Campo & 0,2872 \\
\hline Faz & 0,0780 \\
\hline Total & 1,0000 \\
\hline
\end{tabular}

A taxa de consistência (TC) obtida para os pesos foi de 0,08 , considerada aceitável de acordo com os critérios do método.

\subsubsection{Geração do mapa de probabilidade de visualização do cervídeo}

Os pesos calculados anteriormente foram empregados na elaboração do mapa 
de probabilidade de ocorrência do veado-campeiro no Parque, para a estação seca do ano.

A função empregada foi a Multi-Criteria Evaluation (MCE), que executa a operação de combinação linear ponderada entre os planos, gerando o mapa de probabilidade pretendido (Figura 10).

Examinando-se o histograma da imagem referente ao mapa apresentado na Figura 10, verificou-se que o mesmo apresentava um escala de valores para os pixels, variando do mínimo de 169 até o máximo de 253.

Procedeu-se então à reclassificação dos valores, gerando um mapa com apenas 3 faixas de probabilidade, com seus valores respectivos, dos pixels: A-) Maior (253-225); B-) Média (225-197) e C-) Menor (197-169) (Figura 11). Essa reclassificação teve por finalidade tornar mais objetiva a discussão dos resultados, permitindo uma percepção mais clara, para a analista e possíveis usuários, da graduação obtida para a probabilidade de visualização do animal em relação à área de estudo. 


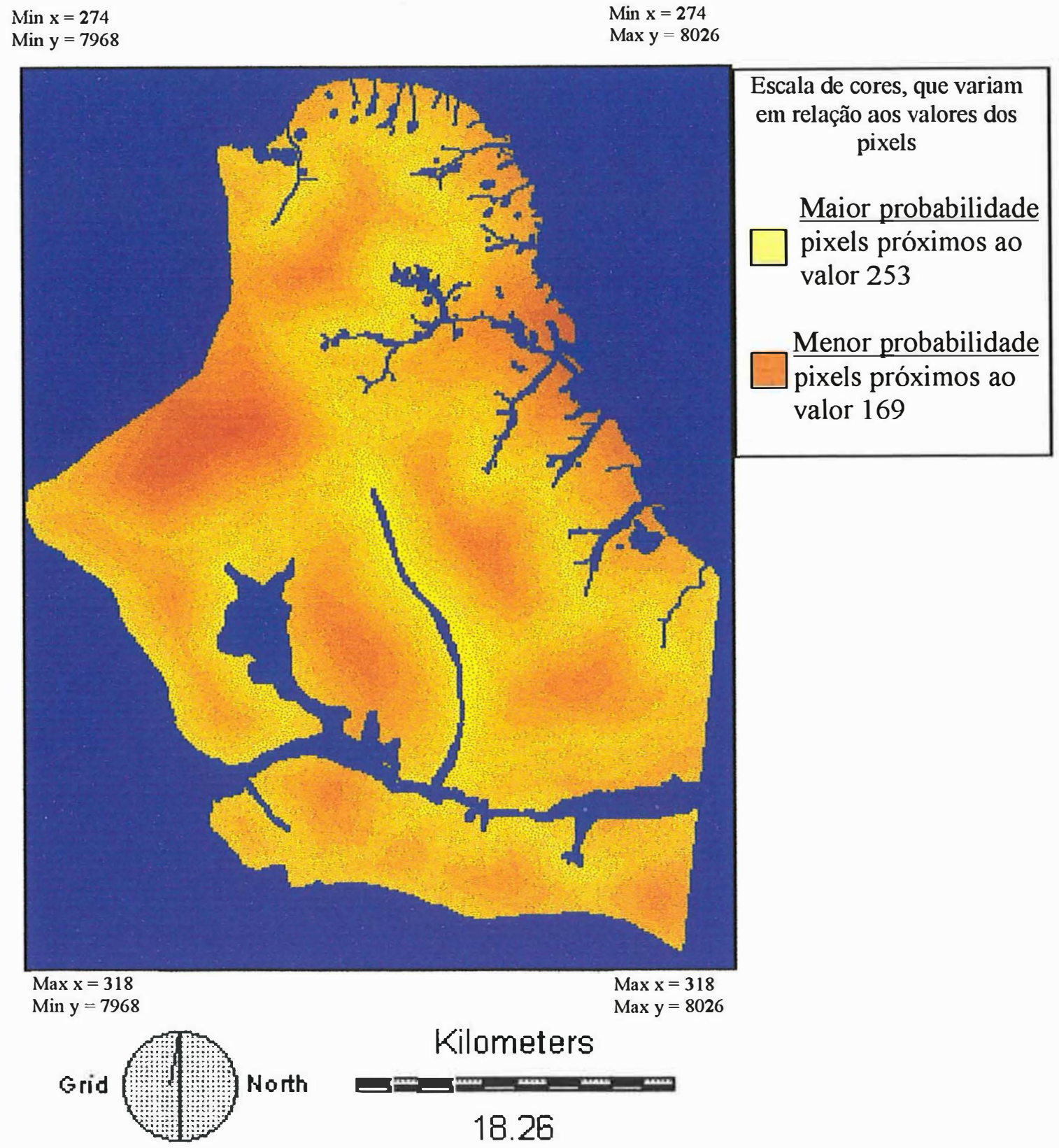

Figura 10 - Mapa de probabilidade de ocorrência do veado-campeiro no Parque Nacional das Emas, para a época seca do ano. 


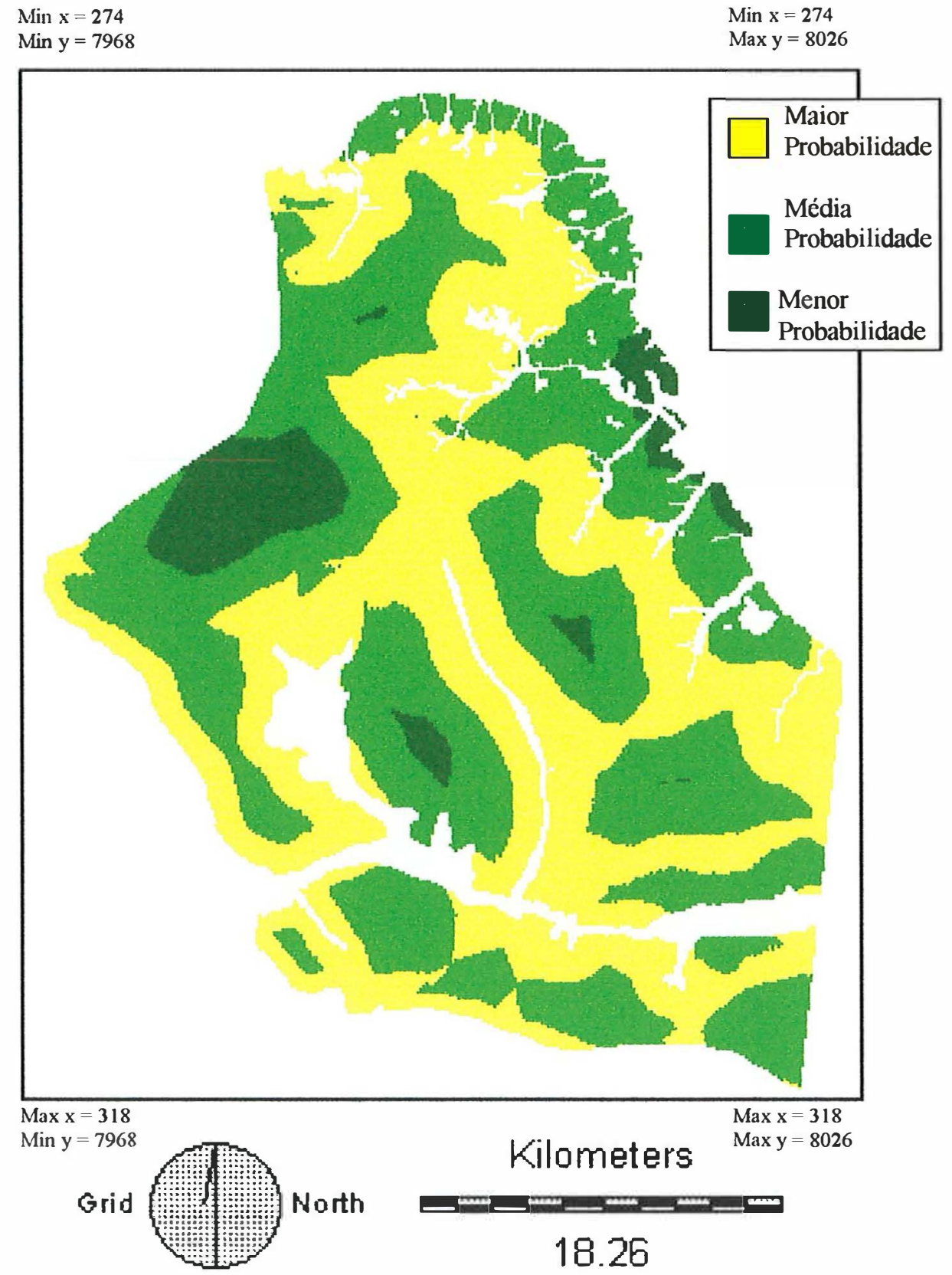

Figura 11 - Mapa de probabilidade de ocorrência do veado-campeiro no Parque Nacional das Emas, reclassificada em três faixas de probabilidade. 


\subsubsection{Checagem dos resultados}

\subsubsection{Levantamentos aéreo e terrestre}

Quanto ao levantamento de julho de 1997, avistou-se 23 animais, em 18 visualizações, sendo 14 em aceiro, 4 em campo sujo, 4 em campo limpo e 1 fora dos limites do Parque em área de plantação.

A visualização feita, fora dos limites do Parque, na área agrícola, era de um macho, que estava à uma distância aproximada de 140 metros da cerca. $\mathrm{O}$ animal retornou ao Parque, em fuga, após observar o avião. Este fato é raro de acontecer nessa época do ano, mas podem ocorrer eventuais saídas dos animais, com retorno, na grande maioria das vezes.

Dos dados obtidos pelo levantamento aéreo estimou-se, conforme os cálculos de densidade, 237 indivíduos em todo Parque, com densidade de 0,18 indivíduos por $\mathrm{Km}^{2}$ (o erro padrão da densidade média foi de 0,1759 e o erro padrão do total de animais estimado foi de 232,04574).

No mês de novembro de 1997, quando foi realizado o levantamento terrestre, foram visualizados, sem recontagem, 27 veados, donde foi estimada uma população de 1.978 animais, com densidade de 1,5 cervídeos por $\mathrm{km}^{2}$ (erro padrão da densidade média foi de 1,515 e o erro padrão do total de animais estimado foi de $1.988,846)$.

Para o mesmo mês em 1996, pelos dados do projeto Cervídeos do Brasil, foram visualizados 30 animais ${ }^{9}$, confirmando-se assim que nessa época, em que o aceiro já está alto e igualado com o campo, o animal se dispersa na região, ficando numa situação mais homogênea.

Rodrigues (1996), estimou 1.319 individuos para o Parque (censo terrestre com recontagem), com estimativa de 1 ind./100 ha. $\mathrm{O}$ autor baseou-se em trabalhos de

\footnotetext{
${ }^{9}$ Dados do Projeto Cervídeos. Devido à metodologia ser diferente da utilizada neste trabalho, não se estimou a população, para se evitar erros de comparação.
} 
Schaller \& Duplaix-Hall ${ }^{10}$ (1975), que estimaram de 1.000 a 1.300 indivíduos no Parque.

É possível que o que tenha causado, a baixa estimativa neste trabalho, na amostragem aérea, tenha sido o som do avião, pois como o veado quase não anda em grupos e tem uma fuga rápida, é possível que alguns indivíduos tenham fugido antes de serem observados pelo pesquisador. Ou mesmo o fato de serem populações flutuantes, que se deslocam muito pela área.

O horário, a altura, a visibilidade, a fadiga do técnico, o reconhecimento do animal pelo mesmo, não foram desfavoráveis, sendo que, realmente eles não estavam nas faixas de visualização. $O$ que faltou para se ter uma maior confirmação, quanto ao levantamento aéreo, foi a realização de um levantamento terrestre no mesmo mês em que ele foi realizado.

Essa necessidade de um levantamento terrestre, praticamente simultâneo ao aéreo, é devido ao fato de no mês de julho (época seca) ocorrer a queimada dos aceiros, havendo uma maior probabilidade de se encontrar uma maior quantidade de animais nesse locais.

Mas o que realmente se recomendaria, para se ter uma melhor aproximação sobre a quantidade aproximada de animais no Parque, é a execução de censo com padrão de amostragem, repetido por no mínimo 2 anos e a cada mês. Estudando os possíveis índices de natalidade, mortalidade, possíveis saídas sem retorno e entrada de animais no Parque. Assim se teria maior confirmação da sazonalidade dos animais em relação aos fenômenos que provocam a sua movimentação, bem como a clareza dos índices de fluxo populacional.

Todas as contagem realizadas no Parque, sempre foram feitas em um mês apenas do ano, necessitando-se um maior acompanhamento das populações para se chegar a valores mais exatos de densidade populacional, reduzindo assim os erros de censo e se estimando índices de natalidade, mortalidade e migração da espécie.

\footnotetext{
${ }^{10}$ Relatório não publicado e citado em Rodrigues (1996).
} 
É interessante notar, em relação aos cálculos estatísticos, que quanto maior a área coberta, menor será o erro padrão da densidade e da estimativa de animais, assim o ideal seria criar a maior quantidade de áreas de transectos possíveis.

A eficiência do vôo apenas para o censo de veado-campeiro no Parque não foi confirmada, mas quanto à determinação de habitat, veio ajudar na confirmação do mapa obtido na análise em ambiente SIG.

$\mathrm{O}$ censo terrestre mostrou-se mais eficiente, aproximando-se dos resultados de Rodrigues (1996), mas com um número maior de estimativa populacional, faltando, como citado anteriormente, para uma maior confirmação da estimativa populacional, repetições, que não puderam ser realizadas.

\subsubsection{Cruzamento do mapa de probabilidade de ocorrência, com os dados do levantamento aéreo}

$\mathrm{Na}$ sobreposição dos dados obtidos pelo levantamento aéreo, com a imagem reclassificada, obteve-se a Figura 12, que mostra a distribuição dos animais avistados nas áreas classificadas como de maior, média e menor probabilidade de ocorrência do veado-campeiro no Parque Nacional das Emas.

Para a análise destes resultados, avaliou-se os dados de distribuição dos animais sobre os pixels dos mapas não-reclassificado e reclassificado, resultando na Tabela 5, onde se pode avaliar a ordenação dos pontos de visualização aérea, com os valores dos pixels e por si só a distribuição pelas faixas de probabilidade de ocorrência, como pode ser notado na Figura 12.

Para melhor visualização dos resultados, gerou-se um histograma, na comparação dos dados aéreos, com a quantidade de pixels e seus devidos valores (Tabela 6). 


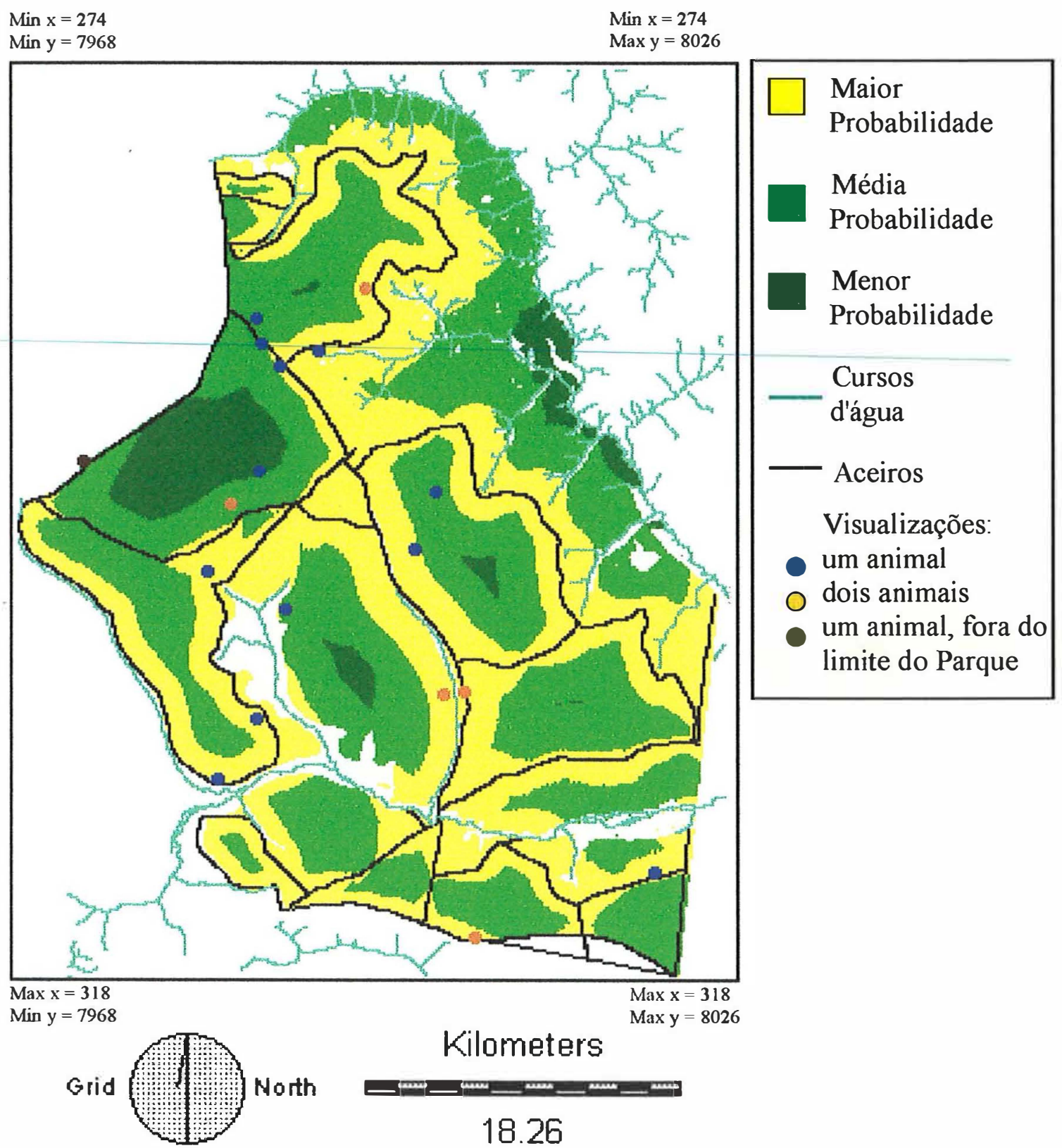

Figura 12 - Superposição dos dados do levantamento aéreo, com o mapa de probabilidade de ocorrência, reclassificado em três faixas de probabilidade. 
Tabela 5 - Distribuição dos animais, segundo os valores de pixels do mapa de probabilidade de ocorrência.

\begin{tabular}{|c|c|c|c|c|}
\hline $\begin{array}{c}\text { Faixas de } \\
\text { probabilidade } \\
\text { de ocorrência }\end{array}$ & $\begin{array}{c}\text { Valor } \\
\text { do } \\
\text { Pixel }\end{array}$ & $\begin{array}{c}\text { Visualizações de } \\
\text { indivíduos isolados } \\
\text { por pixel }\end{array}$ & $\begin{array}{c}\text { Visualizaçóes de } \\
\text { grupos de animais } \\
\text { (dois indivíduos), } \\
\text { por pixel. }\end{array}$ & $\begin{array}{c}\text { Total de } \\
\text { animais } \\
\text { por pixel }\end{array}$ \\
\hline Menor & 0 & 0 & 0 & 0 \\
& 194 & 1 & 0 & 1 \\
\hline \multirow{5}{*}{ Média } & 213 & 1 & 0 & 1 \\
& 214 & 0 & 1 & 2 \\
& 215 & 1 & 0 & 1 \\
& 219 & 1 & 0 & 1 \\
& 223 & 1 & 0 & 1 \\
\hline \multirow{5}{*}{ Maior } & 227 & 2 & 0 & 2 \\
& 229 & 1 & 1 & 3 \\
& 235 & 1 & 1 & 3 \\
& 238 & 1 & 0 & 1 \\
& 240 & 0 & 1 & 2 \\
\hline & 241 & 2 & 0 & 2 \\
\hline
\end{tabular}

Tabela 6 - Histograma do cruzamento dos dados do levantamento aéreo, com a quantidade de pixels e seus devidos valores, em relação às faixas de distribuição do veado-campeiro.

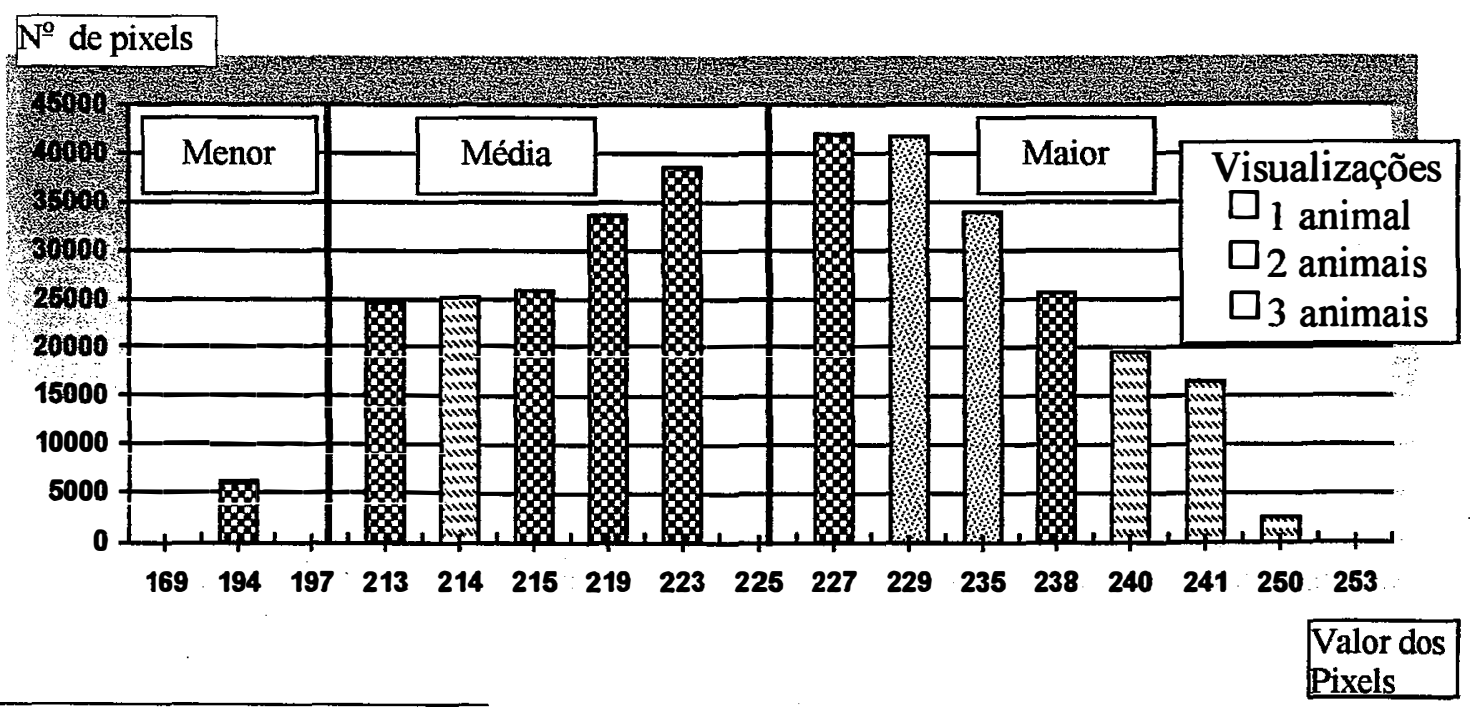

* Ocorreu apenas uma visualização de um indivíduo, fora dos limites do Parque. Este dado não foi computado para estudo de distribuição, como é explicado no texto, mas foi incluído nos cálculos de censo. 
A análise estatística foi aplicada, cruzando-se primeiramente a imagem reclassificada (Figura 11) com a amostragem aérea, obtendo-se os resultados visuais indicados na Figura 12, que analisados por linha de transectos de visualização, originaram a contagem descrita na Tabela 7 .

As visualizações nos transectos, por faixa de probabilidade, foram anotadas, com a quantidade de animais por visualização. Os transectos, ou trecho deles, sem anotações, indicam a situação "fora dos limites do Parque" (Tabela 7). 
Tabela 7 - Cruzamentos dos dados aéreos, por transecto, com o mapa contendo as faixas de probabilidade de ocorrência.

\begin{tabular}{|c|c|c|c|}
\hline & \multicolumn{3}{|c|}{ VISUALIZAÇÕES } \\
\hline $\begin{array}{c}\text { Transectos aéreos } \\
\text { horizontais }\end{array}$ & $\begin{array}{c}\text { Faixa A } \\
\text { (Alta ) }\end{array}$ & $\begin{array}{l}\text { Faixa B } \\
\text { (Média) }\end{array}$ & $\begin{array}{l}\text { Faixa C } \\
\text { (Baixa) }\end{array}$ \\
\hline \multicolumn{4}{|l|}{1} \\
\hline 2 & 2 & 0 & \\
\hline 3 & 0 & 0 & \\
\hline 4 & 1 & 0 & \\
\hline 5 & 0 & 0 & \\
\hline 6 & 0 & 0 & \\
\hline 7 & 1 & 0 & \\
\hline 8 & 0 & 0 & \\
\hline 9 & 1 & 0 & \\
\hline 10 & 4 & 0 & 0 \\
\hline 11 & 0 & 0 & 0 \\
\hline 12 & 0 & 1 & \\
\hline 13 & 1 & 0 & 0 \\
\hline 14 & 1 & 0 & \\
\hline 15 & 0 & 2 & 0 \\
\hline 16 & 0 & 1 & 1 \\
\hline 17 & 0 & 0 & 0 \\
\hline 18 & 0 & 0 & 0 \\
\hline 19 & 1 & 0 & 0 \\
\hline 20 & 1 & 1 & 0 \\
\hline 21 & 0 & 1 & 0 \\
\hline 22 & 2 & 0 & 0 \\
\hline 23 & 0 & 0 & \\
\hline 24 & 0 & 0 & \\
\hline 25 & 0 & 0 & \\
\hline 26 & 0 & 0 & \\
\hline 27 & & 0 & \\
\hline \multicolumn{4}{|l|}{28} \\
\hline Total & 15 & 6 & 1 \\
\hline Média & 0,6 & 0,23 & 0,09 \\
\hline
\end{tabular}

Para comparação dos tratamentos, por meio de uma análise de variância nãoparamétrica, empregou-se o teste de Kruskal-Wallis, com nível de significância de 10\%, obtendo-se o resultado $\mathbf{P}=0,0803$, demonstrando assim que houve diferença 
significativa entre os tratamentos.

Em repetição do mesmo teste de Kruskal-Wallis, a cada dois tratamentos, comparou-se as diferenças entre os mesmos, reconhecendo que as ocorrências de animais no tratamento A (faixa de maior probabilidade de ocorrência) eram significativamente maior que nas faixas $\mathrm{B}$ (média probabilidade de ocorrência) e $\mathrm{C}$ (baixa probabilidade de ocorrência), tornando os resultados, estatisticamente satisfatórios (Tabela 8).

Tabela 8 - Comparação dos tratamentos.

\begin{tabular}{|c|c|c|}
\hline Tratamentos & Valor de $\mathbf{P}$ & Resultado \\
\hline A e B & 0,0964 & Diferente $\mathbf{P}<0,10$ \\
\hline A e C & 0,0618 & Diferente $\mathbf{P}<0,10$ \\
\hline B e C & 0,4361 & Igual $\mathbf{P}>0,10$ \\
\hline
\end{tabular}

Uma análise percentual simples do cruzamento entre a imagem reclassificada em três faixas de probabilidade de ocorrência e os dados aéreos, resultou que $68,18 \%$ dos animais visualizados estavam na faixa de maior probabilidade de ocorrência; $27,27 \%$ estavam na faixa de média probabilidade de ocorrência; e $4,55 \%$ encontravamse na faixa de menor probabilidade de ocorrência no Parque.

Assim, a análise estatística, com emprego do devido teste, e uma comparação percentual, demonstraram que os locais de maior probabilidade de ocorrência, na distribuição dos veados-campeiros no Parque, podem ser determinados pelo SIG, conforme a metodologia empregada neste estudo.

\subsubsection{Cruzamento do mapa de probabilidade de ocorrência, com os dados do levantamento terrestre}

No cruzamento do mapa com as três faixas de probabilidade de ocorrência do veado-campeiro, com os dados de visualização terrestre, detectou-se que os dados 
obtidos pelo levantamento terrestre, nas estradas do Parque, estavam viciados, como mostra a Figura 13. Isto se deve pelo fato deste método limitar-se à visualização dos animais em uma estreita faixa de $50 \mathrm{~m}$ de cada lado da estrada, não na totalidade do Parque.

Assim este método não foi eficiente quanto à determinação da distribuição da espécie, mas quanto ao estudo das características biológicas e comportamentais do animal, e possíveis censos, demonstrou ser adequado. 


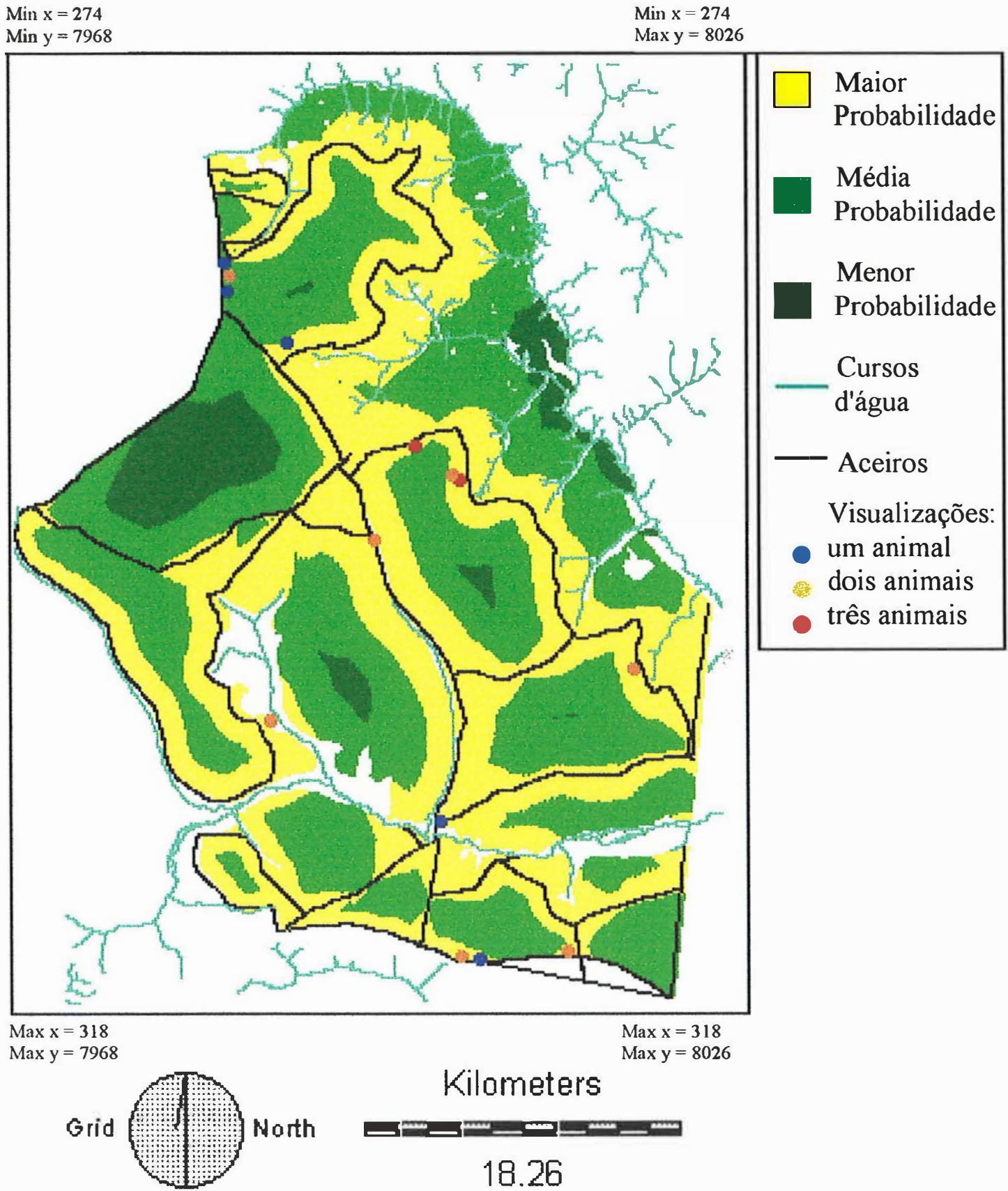

Figura 13 - Superposição dos dados do levantamento terrestre, com o mapa de probabilidade de ocorrência reclassificado. 


\subsubsection{Possibilidades de emprego do SIG no Parque Nacional das Emas}

Acredita-se ser possível a realização de trabalhos no Parque, com manejo de fogo, corredores biológicos e delimitações de territórios, favorecendo o estabelecimento de critérios para a conservação e manejo das áreas do PNE, bem como da vida silvestre presente.

a-) Manejo do fogo

O manejo do fogo no Parque Nacional das Emas, com o uso de SIG, poderia ser viável, para amenizar o impacto do fogo sobre o Parque, controlando as regiões de maior concentração de fitomassa, para se evitar queimadas em grande escala.

Poderia também ser empregado na determinação de locais mais atrativos para a fauna, por meio de queimadas controladas da vegetação, para amenizar as saídas dos animais para áreas agrícolas, nas épocas de plantio e de colheita, evitando o contato com agrotóxicos e possíveis atropelamentos nas estradas.

b-) Corredores biológicos e delimitação de territórios

É possível, por meio da metodologia estudada, o mapeamento de possíveis corredores biológicos no Parque. Isto foi sugerido por observações feitas sobre as imagens de satélite, na região do Jacuba (cerrado "strictu senso" e mata ciliar) e diretamente nestes locais, onde se avistaram, em inúmeras ocasiões, pegadas de veadoscampeiros em aceiros e estradas.

Apesar de não serem locais de ocorrência (regiões fechadas), estes ambientes, por possuírem estradas e aceiros, comportam-se, para os veados-campeiros, como corredores de passagem para fora dos limites do Parque e possivelmente de entrada para outras populações de fora do Parque.

Esta característica dos veados de não permanecerem em regiões fechadas, dáse como defesa contra predadores, geralmente onça-pintada (Panthera onca) e onça- 
parda ou suçuarana (Puma concolor), que habitam principalmente estas áreas, que margeiam os cursos d'água, pois são locais estratégicos para capturarem suas presas, que vão em busca d'água.

Como sempre se encontraram em regiões próximas a mata ciliar, e mesmo na região do Jacuba, pegadas de onça-pintada (Panthera onca) e onça-parda (Puma concolor), no rastro de veado-campeiro, este poderia ser um animal indicador, dentre as presas dos felinos, que ajudaria na determinação das rotas de movimentação dos felinos e confirmar os locais de maior ocorrência dos mesmos. Assim, a partir do estudo dos deslocamentos dos felinos, poderia-se utilizar o SIG para mapeamento de territórios dos predadores. 


\section{CONCLUSÕES}

1-) A metodologia empregada mostrou-se eficiente no mapeamento da distribuição do veado-campeiro (Ozotoceros bezoarticus), determinando áreas de diferentes probabilidades de ocorrência do animal, no Parque Nacional das Emas, em Goiás. Os resultados demonstraram que os Sistemas de Informações Geográficas podem ser empregados com sucesso na análise da distribuição do veado-campeiro.

2-) A técnica participatória permitiu definir com eficiência os fatores responsáveis pela distribuição do animal no Parque, bem como seus respectivos pesos.

3-) A análise estatística empregada (teste de Kruskal-Wallis) acusou diferença entre tratamentos, mostrando que o número de animais visualizados, por meio de checagem aérea, foi significativamente maior na área mapeada como de maior probabilidade de ocorrência, que naquelas mapeadas como de média e menor probabilidades.

4-) Foi essencial para a realização deste projeto com eficiência: a-) a existência de um bom banco de dados sobre o animal (comportamental e fisiológicos) e sobre os ambientes do Parque; b-) a visita e a convivência no local de estudo, para se conhecer a região, o animal e manter contato com pessoas que moravam ou já trabalhavam há um bom tempo com a espécie, colhendo mais informações, para que fosse possível selecionar adequadamente os planos necessários para a análise, com seus devidos pesos relativos. 
5-) A amostragem aérea foi de fundamental importância na checagem dos resultados obtidos no mapeamento de probabilidade da distribuição e determinação dos locais de ocorrência da espécie. 


\section{REFERÊNCIAS BIBLIOGRÁFICAS}

AGEE, J.K.; STITT, S.C.F.; NYQUIST, M. et al. A geographic analysis of historical grizzly bear sightings in the North Cascades. Photogrammetric Engineering \& Remote Sensing, v.55, n.11, p.1637-1642, Nov.1989.

ANDERSON, W.H.; WENTZ, W.A.; TREADWELL, B.D. Una guía sobre información de sensores remotos para biólogos especializados en vida silvestre. In: SCHENMITZ,S.D. Manual de técnicas de gestión de vida silvestre. Canada: Wildlife Society, 1987. Cap.18, p.305-320.

ASPINALL, R.; VEITCH, N. Habitat mapping from satellite imagery and wildlife survey data using a bayeasin modeling procedure in a GIS. Photogrammetric Engineering \& Remote Sensing, v.59, n.4, p.537-543, april.1993.

ASPINALL, R.; MATTHEWS,K. Climate change impact on distribution and abundance of wildlife species: an analytical approach using GIS. Environmental Pollution, v.86, p.217-223, 1994.

AZEVEDO, L. G.; VERDESIO, J.J. O uso de sensores remotos e do processamento de dados na identificação de ambientes de importância zoogeográficas. In: CONGRESSO BRASILEIRO DE PRIMATOLOGIA, 1., Belo Horizonte, 1983. Anais. Belo Horizonte: SPB, 1983, p.341-355.

BARNES, R.F.W.; DOUGLAS-HAMILTON, I. The numbers and distribution patterns of large mammals in the Ruaha-Rungwa area of souther Tanzania. Journal of Applied Ecology, n. 19, p. 411- 425, 1982. 
BOJÓRQUEZ-TAPIA, L.A.; AZUARA, I.; EZCURRA, E. Identifying conservation priorities in Mexico through geographic information systems and modeling. Ecological Applications, v.5, n.1, p.215-231, 1995.

BRAZO, F.; SORIGUER, R.C.; SAN JOSE, C.et al. Metodos para el estudio y manejo de cervidos. Junta de Andalucia: Consejeria de Meio Ambiente, 1994. 80 p.

CAMPOS, H. de. Estatística Experimental Não-Paramétrica. Piracicaba: ESALQ/USP, 1979. 343p.

CARVALHO,C.T. Veado campeiro (Ozotoceros bezoarticus): situação e distribuição. Piracicaba: IPEF, dez.1977. no 7, p.21: Boletim técnico.

CAUGHLEY, G. Analysis of vertebrate populations. New York: John Wiley \& Sons. 1980. 234p.

CHANG, K.T.; VERBYLA, D.L.; YEO, J.J. Spatial analysis of habitat selection by sitka black - tailed deer in Southeast Alaska, USA. Environmental Management, v.19, n.4, p.579-589, 1995.

CLARK, J.D.; DUNN, J. E. D.; SMITH, K.G. A multivariate model of female black bear habitat use for a geographic information system. The Journal of Wildlife Management, v.57, n.3, p.519-526,1993.

CONGALTON, R.G.; STENBACK, J.M.; BARRET, R.H. Mapping deer habitat suitability using remote sensing and geographic information systems. Geocarto International, v.8, n.3, sept. 1993. 
COUTINHO, L.M. Os cerrados do Parque Nacional das Emas, suas queimadas e alguns outros problemas de manejo. In: CONGRESSO NACIONAL DE BOTÂNICA, 7., Campinas, 1990. Resumos. Campinas: SBSP, 1990. p. 75-76.

COUTINHO, L.M. O cerrado - ecologia do fogo. Ciência Hoje, v.12, n.68, nov. 1990.

COUTINHO, L.M. O Parque Nacional das Emas, sua queimadas e problemas de manejo. In: CONGRESSO NACIONAL DE BOTÂNICA, 42., Goiânia, 1991. Resumos. Goiânia: SBG, 1991. p.141.

CRAVINO, J.L. La situacion del venado de campo en Uruguay. Flora e Fauna y Areas Silvestres, Santiago,v.2, n.6, p.28-31, jan/abri.1988.

DEUTSCH, L.; PUGLIA, L.R.R. Os animais silvestres; proteção, doenças e manejo. Rio de Janeiro: Publicações Globo Rural, 1988. Coleção do Agricultor, 191p.

EASTMAN, J.R. Idrisi: use's guide. Worcester, Massachusetts, USA: Clark University, 1992. $178 \mathrm{p}$.

EASTMAN, J.R.; KYEM, P.A.K.; TOLEDANO, J. et al. Gis and decision making: Explorations in Geographic Information Systems Technology. Genebra: UNITAR, 1993. v.4, 112p.

EASTMAN, J.R.; JM, W.; KYEM, P.A.K. et al. Raster procedures for multicriteria/multi-objective decisions. Photogrammetric Engineering \& Remote Sensing, v.61, n.5, p.539-547, May.1995.

EBERHARDT, L.L. Transect methods for population studies. The Journal of Wildlife Management, v.42, n.1, p.1-31, 1978. 
FIRKOWSKI,C. O Habitat para a fauna. In: CONGRESSO FLORESTAL BRASILEIRO, 6., Trabalhos Convidados v.1, Campos do Jordão, 1990. Anais. Campos do Jordão, IF , 1990. p.139-143.

FONSECA, G.A.B.; RYLANDS, A.B.; COSTA, C.M.R. et al. Veado-Campeiro (Ozotoceros bezoarticus). In: FONSECA,G.A.B.; RYLANDS,A.B.; COSTA,C.M.R. et al. Livros vermelho dos mamíferos brasileiros ameaçados de extinção. Belo Horizonte: Fundação Biodiversitas, 1994. p.411-417.

FONSECA, G.A.B.; HERMANN, G. ; LEITE , Y.L.R. et al. Lista Anotada dos Mamíferos do Brasil. Occasional Papers in Conservation Biology, n.4, p.1-38, abr.1996.

GOODLAND, R.; FERRI, M. G. Ecologia do Cerrado. Belo Horizonte: Edusp, 1979. $193 p$.

GREEN, K.M.; LYNCH, J.F.; SIRCAR, Y. et al. Landsat remote sensing to assess habitat for migratory birds in the Yucatan peninsula, Mexico. Vida Silvestre Neotropical, v.1, n.2, p.27-38, 1987.

HALL, J.B. Mapping for monographs: baselines for resources development. In: MILLER, R.I. Mapping the diversity of nature. London: Chapman \& Hall, 1994. Cap. 2, p.21-35.

HILL, G.J.E.; KELLY, G.D. Habitat mapping by landsat for aerial census of kangaroos. Remote Sensing of Environment, n.21, p.53-60, 1987.

IBDF/FBCN. Plano de Manejo: Parque Nacional das Emas - PNE. Brasília: IBDF/FBCN, 1981. $901 \mathrm{p}$. 
JACKSON, J.E. Ozotoceros bezoarticus. Mammalian Species, The american society of mammalogists, n.295, p.1-5, aug. 1987.

JACKSON, J.E.; LANGGUTH, A. Ecology and status of the pampas deer in Argentinian pampas and Uruguay. In: Smithsonian Institution. Biology and management of the cervidae. Washington: Christen M. Wemmer, aug.1982. p.402-409.

KEAY, J. A., PEEK, J. M. Relationships between fires and winter habitat of deer in Idaho. The Journal of Wildlife Management, v.44, n.2, p.372-380, 1980.

KNICK, S.T.; DYER, L.D. Distribution of black-tailed jackrabbit habitat determined by GIS in southwestern Idaho. The Journal of Wildlife Management, v.61, n.1, p.7585, 1997.

MacKINNON, J.; WULF, R. De. Designing protected areas for giant pandas in China, In: MILLER,R.I. Mapping the diversity of nature. London: Chapman \& Hall, 1994. Cap.8, p.127-142.

MANEN, F.T. van., PELTON, M.R. A GIS model to predict black bear habitat use. Journal of Forestry, v.97, n.6, p.6-12, Aug. 1997.

MARCH, I.J.; MIDENCE, S. Guia practica: preliminar para el uso de sistemas de informacion geografica y sensores remotos en el estudio y manejo del habitat de fauna silvestre. Flora Fauna y Areas Silvestres, v.3, n.11, p.28-32, Dez. 1989.

MAURO, R.A. Abundância e padrão de distribuição de Cervo-do-Pantanal (Blastocerus dichotomus) no Pantanal Mato-Grossense. Belo Horizonte, 1993. 48p. Dissertação (MS) - Universidade Federal de Minas Gerais. 
McLAREN, S.B.; BRAUN, J.K. GIS applications in mammalogy. Oklahoma, USA: Oklahoma Museum of Natural History, 1993. 41 p.

MICHELMORE, F. Keeping elephants on the map: Case studies of the application of GIS for conservation. In: MILLER, R.I. Mapping the diversity of nature. London: Chapman \& Hall, 1994. Cap.7, p. 107-125.

MILLER, R.I. Setting the scene. In: MILLER, R.I. Mapping the diversity of nature. London: Chapman \& Hall, 1994. Cap.1, p.03-17.

MILLER, R.I.; ALLEN, J.H. Mapping the elements of biodiversity: The rare species of Madagascar. In: MILLER, R.I. Mapping the diversity of nature. London: Chapman \& Hall, 1994. Cap.3, p.37-51.

MINISTÉRIO DO MEIO AMBIENTE. Prioridades para conservação da Biodiversidade da Mata Atlântica do nordeste. In: Workshop Mata Atlântica do Nordeste, Pernambuco, dez.1993. Escala: 1:2.500.000.

MLADENOFF, D.J.; SICKLEY, T.A; HAIGHT, R.G. et al. A regional landscape analysis and prediction of favorable gray wolf habitat in the northern great lakes region. Conservation Biology, v.9, n.2, p.279-294, Apr.1995.

MOURÃO, G.M.; MAGNUSSON, W. Uso de levantamento aéreos para o manejo de populações silvestres. In: VALLARES-PADUA, C.; BODMER,R.E.; CULLEN Jr,L. Manejo e Conservação de Vida Silvestre no Brasil. Brasilia/Belém: CNPq/Sociedade Civil Mamirauá, 1997. Cap.2, p.23-33.

OLIVEIRA-FILHO, A.T. de., FURLEY, P.A. Monchão, cocuruto, murundu. Ciência Hoje, v.11, n.61, jan/fev, 1990. 
PALMEIRIM, J.M. Automatic mapping of avian species habitat using satellite imagery. Oikos, v.52, n.1, p59-68, nov.1988.

PETERSON, D. E. Grizzly country: GPS/GIS help monitor the great bear's fragile ecossystem. Gis World, v.9, n.4, p.52-55, Apr.1996.

PINDER, L. Estimativa de populações de cervos-do-pantanal no rio Paraná utilizando levantamento aéreo. In: VALLARES-PADUA, C.; BODMER,R.E.; CULLEN Jr,L. Manejo e Conservação de Vida Silvestre no Brasil. Brasilia/Belém: CNPq/Sociedade Civil Mamirauá, 1997. Cap.8, p.116-122.

PORWAL, M.C.; ROY, P.S.; CHELLAMUTHU, V. Wildlife habitat analysis for "sambar" (Cervus unicolor) in Hanha National Park using remote sensing. International Journal Remote Sensing, v.17, n. 14, p. 2683-2697, 1996.

REDFORD, K.H. The pampas deer (Ozotoceros bezoarticus) in central Brazil. In: Smithsonian Institution. Biology and management of the cervidae. Washington: Christen M. Wemmer, aug.1982. p. 410-414.

REDFORD, K.H. Lista preliminar de mamíferos do parque nacional das emas. Brasil Florestal, v. 55, p.29-33, jul./ago/set.1983.

REDFORD, K.H. Parque das Emas. Ciência Hoje, v.7, n.38, p.42-48, Dez.1987.

RODRIGUES, F.H.G. História natural e biologia comportamental do veado campeiro (Ozotoceros Bezoarticus) em cerrado do Brasil central. Campinas, 1996. 89p. Dissertação (MS) - Universidade de Campinas. 
SCOTT, J.M.; DAVIS, F.; CSUTI, B. et al. Gap analysis: A geographic approach to protection of biological diversity. Wildlife monographic, v.57, n.123, p.1-41, Jan.1993.

SILVA, L.L. Ecologia: manejo de áreas silvestres. Santa Maria: NMA, FNMA, FATEC, 1996. 352p.

SOARES, A.F. Sensoriamento remoto e geoprocessamento aplicados na caracterização dos solos e da cobertura vegetal na bacia hidrográfica do rio candiru-açu (PA). Piracicaba, 1994. 138p. Dissertação (MS) - Escola Superior de Agricultura "Luiz de Queiroz", Universidade de São Paulo.

SPECHT, J. Mapping earth's endangered biodiversity. Gis World, v.9, n.3, p.42-46, Mar.1996.

STORER, T.I.; USINGER, R.L.; STEBBINS, R.C. et al. Zoologia Geral. São Paulo: Companhia Editora Nacional, 1989. cap.12, p.200-233: Ecologia e distribuição dos animais.

SWANK, W.G.; WATSON, R.M.; FREEMAN, G.H. et al. Proceedings of the workshop on the use of light aircraft in wildlife management in east Africa. East African Agriculture and Forestry Research Organization, Kilaguni Lodge, 9-11 December 1968.

TOMÁS, W.M. Observações preliminares sobre densidades e estrutura de grupos de veado-campeiro no pantanal da Nhecolância, Corumbá, MS. In: CONGRESSO BRASILEIRO DE ZOOLOGIA, 15., Paraná, 1988. Resumos. Paraná: SBZ, 1988. p.544. 
VETTORAZZI, C.A. Sensoriamento Remoto Orbital - Série Didática ํํ 2. Piracicaba, São Paulo: Departamento de Engenharia Rural, 1992. 134p.

WALKER, P.A. Modelling wildlife distributions using a geographic information system: kangaroos in relation to climate. Journal of Biogeography, v.17, p.279$289,1990$.

WHITE, G.C., BARTMANN, R.M. CARPENTER L.H. et al., Evaluation of aerial line transects for estimating mule deer densities. The Journal of Wildlife Management, v.53, n.3, p.625-635, 1989.

WORAH, S.; BRARUCHA, E.K.; RODGERS, W. A. The use of geographic information systems in identifying potential wildlife habitat. Journal of the Bombay Natural History Society, v.86, n.2, p.125-128, Aug.1989.

ZAR, J.H. Biostatistical Analysis. London: Prentice-Hall, Englewood Cliffs, N.J., 1984. $718 \mathrm{p}$. 